\title{
Emission of trace gases and aerosols from biomass burning - an updated assessment
}

\author{
Meinrat O. Andreae ${ }^{1,2}$ \\ ${ }^{1}$ Max Planck Institute for Chemistry, Mainz, Germany \\ ${ }^{2}$ Scripps Institution of Oceanography, University of California San Diego, La Jolla, California, USA \\ Correspondence: Meinrat O. Andreae (m.andreae@mpic.de)
}

Received: 29 March 2019 - Discussion started: 4 April 2019

Revised: 2 June 2019 - Accepted: 9 June 2019 - Published: 4 July 2019

\begin{abstract}
Since the publication of the compilation of biomass burning emission factors by Andreae and Merlet (2001), a large number of studies have greatly expanded the amount of available data on emissions from various types of biomass burning. Using essentially the same methodology as Andreae and Merlet (2001), this paper presents an updated compilation of emission factors. The data from over 370 published studies were critically evaluated and integrated into a consistent format. Several new categories of biomass burning were added, and the number of species for which emission data are presented was increased from 93 to 121. Where field data are still insufficient, estimates based on appropriate extrapolation techniques are proposed. For key species, the updated emission factors are compared with previously published values. Based on these emission factors and published global activity estimates, I have derived estimates of pyrogenic emissions for important species released by the various types of biomass burning.
\end{abstract}

\section{Introduction}

Biomass burning, in the form of open vegetation fires and indoor biofuel use, is one of the largest sources of many trace gases and aerosols to the global atmosphere. For some important atmospheric pollutants, like black carbon (BC) and primary organic aerosol (POA), biomass burning is the dominant global source; based on the estimates of Bond et al. (2013), it accounts for $59 \%$ of BC emissions and $85 \%$ of POA emissions worldwide. Open vegetation fires alone represent about one-third to one-half of global carbon monoxide (CO) and $20 \%$ of nitrogen oxide $\left(\mathrm{NO}_{x}\right)$ emissions (Olivier et al., 2005; Wiedinmyer et al., 2011). Fires are also a major source of greenhouse gases, including carbon dioxide $\left(\mathrm{CO}_{2}\right)$, methane $\left(\mathrm{CH}_{4}\right)$, and nitrous oxide $\left(\mathrm{N}_{2} \mathrm{O}\right)$ (Ciais et al., 2013; Tian et al., 2016; Le Quéré et al., 2018). While a significant fraction of the emitted $\mathrm{CO}_{2}$ is taken up again by vegetation regrowth, much of it remains in the atmosphere for years and potentially even up to centuries, e.g., in the case of tropical deforestation fires or peat soil burning (van der Werf et al., 2017). Model simulations suggest that in the absence of fires, atmospheric $\mathrm{CO}_{2}$ concentrations would be about $40 \mathrm{ppm}$ lower, indicating the importance of fires for the atmospheric carbon budget and climate (Ward et al., 2012). Biomass burning is the second largest global source of nonmethane organic gases (NMOGs, also referred to as volatile organic compounds, VOCs) (Yokelson et al., 2008; Akagi et al., 2011). Numerous other studies have reached similar conclusions about the importance of biomass burning for atmospheric composition (e.g., Crutzen and Andreae, 1990; Andreae and Rosenfeld, 2008; Andreae et al., 2009; Kaiser et al., 2012; van der Werf et al., 2017).

The resulting perturbations of the atmospheric burdens of trace gases and aerosols have important consequences for climate, biogeochemical cycles, and human health. Aerosols from biomass burning affect the regional and global radiation balance and impact cloud properties and precipitation (Andreae et al., 2004; Andreae and Rosenfeld, 2008; Rosenfeld et al., 2008, 2014; Ward et al., 2012; Tosca et al., 2013; Jiang et al., 2016; Braga et al., 2017; Cecchini et al., 2017; Hamilton et al., 2018; Thornhill et al., 2018). By shifting the proportions of direct and indirect solar radiation, they also influence primary productivity and thereby forest growth and agricultural production (Artaxo et al., 2009; Rap et al., 
2015; Malavelle et al., 2019; McKendry et al., 2019). Fires mobilize nutrients, such as nitrogen, phosphorus, and potassium, which can deplete local ecosystem nutrient reservoirs on the one hand and provide nutrients to other ecosystems by atmospheric transport on the other (Andreae, 1991; Andreae et al., 1998; Mahowald et al., 2008; Y. Chen et al., 2010). The VOCs and $\mathrm{NO}_{x}$ in biomass smoke undergo smog photochemistry in the atmosphere, leading to the production of ozone, secondary organic aerosols, and other pollutants, which impact plant productivity (Crutzen and Andreae, 1990; Andreae, 1991; Robinson et al., 2007; Jaffe and Wigder, 2012; May et al., 2013; Pacifico et al., 2015; Hatch et al., 2017; Yue and Unger, 2018). These gaseous pollutants, and even more so the particulate matter from biomass burning, pose grave risks to human health (Naeher et al., 2007; Akagi et al., 2014; Dennekamp et al., 2015; Knorr et al., 2017; Apte et al., 2018). Recent estimates of global excess mortality from outdoor air pollution range from 4.2 to 8.9 million annually (Cohen et al., 2017; Lelieveld and Pöschl, 2017; Shiraiwa et al., 2017; Burnett et al., 2018; Lelieveld et al., 2019), with smoke from open vegetation burning accounting for up to 600000 premature deaths per year globally (75th percentile of model estimates; Johnston et al., 2012). In addition to outdoor exposure, pollution from indoor solid fuel use, much of it biofuel burning, has been estimated to cause 2.8 million premature deaths annually (Kodros et al., 2018).

In view of the immense impact of biomass burning emissions on climate, ecosystem function, and human wellbeing, it is disconcerting that large uncertainties persist regarding the amounts emitted and their spatial and temporal distribution. For bottom-up emissions estimates, two basic types of information are required: the amount of the various types of biomass burned as a function of time and space and the emission factors for the various emitted species, i.e., the amount of a given species emitted per unit mass of biomass burned. Considerable effort has gone into quantifying the magnitude of open biomass burning by remote-sensing approaches (Mouillot et al., 2006; Reid et al., 2009; Mieville et al., 2010; Wiedinmyer et al., 2011; Kaiser et al., 2012; Ichoku and Ellison, 2014; Darmenov and da Silva, 2015; Chuvieco et al., 2016; van der Werf et al., 2017), but the estimates in these studies of the annual amounts of carbon released still range over a factor of 3 from 1.5 to $4.7 \mathrm{Pg} \mathrm{a}^{-1}$. A model intercomparison based on state-of-the-art dynamic global vegetation models (DVGMs) yielded an even wider range of 1.0 to $4.9 \mathrm{Pg} \mathrm{a}^{-1}$ (F. Li et al., 2019).

Efforts to narrow the uncertainties in the emission factors for the large number of species emitted from the diverse types of burning are ongoing in the form of numerous field campaigns and laboratory studies. The results of these studies are, however, widely dispersed among hundreds of papers in a large number of journals, each dealing with a particular campaign or experiment. Over the last two decades, there have been two efforts to synthesize these data on a global scale, one by Andreae and Merlet (2001; hereafter referred to as A\&M2001) and the other by Akagi et al. (2011). The latter included more recent data and additional species and burning types and is available in updated form at http://bai.acom.ucar.edu/Data/fire/ (last access: 27 June 2019). As part of the Fire INventory from NCAR (FINN) model, Wiedinmyer et al. (2011) selected data from these two sources into a "best estimate" set of emission factors.

In the present study, I am presenting an updated set of emission factors, which includes the results of studies published since the writing of the two previous compilations. It provides emission estimates for 28 more chemical species, for which a sufficient amount of field data has become available since A\&M2001, as well as an extended set of burning types. The extratropical forest category is differentiated into boreal and temperate forest burning, domestic biofuel use is separated into non-dung and dung burning, and peat fires and domestic waste burning are added as new categories. Based on these emission data and recent activity estimates, I present a compilation of global emission amounts and make some recommendations regarding priorities for future investigations.

\section{Methods}

\subsection{Data selection}

This paper applies the same methodological approach as A\&M2001, and therefore the Methods section will only provide a brief overview of the definitions and calculation methods used and highlight those points where the present approach differs from the previous one. For all other details, the reader is referred to A\&M2001. The original data, which form the basis of the emission factor averages presented in Table 1, can be found in an Excel spreadsheet in the Supplement.

With few exceptions, and consistent with the approach used in A\&M2001, I only used results from field measurements in young fire plumes for the compilation of the emission factor data in Table 1. Ideally, these measurements had been made within minutes after the smoke was released from the fires to avoid significant chemical changes during atmospheric aging, especially in the case of reactive trace gases. This is only possible, however, when sampling at the ground or from aircraft very close to the fire. In many other cases, aircraft were sampling at some distance from the fires, often without actually knowing the exact location of the fire. In such cases, I have rejected the data for the more reactive trace gases. A special case is presented by emission data calculated from remote sensing by either satellite measurements or ground-based solar Fourier transform infrared (FTIR) spectrometry. Here, the authors have often included a correction for atmospheric transformations, using model calculations 


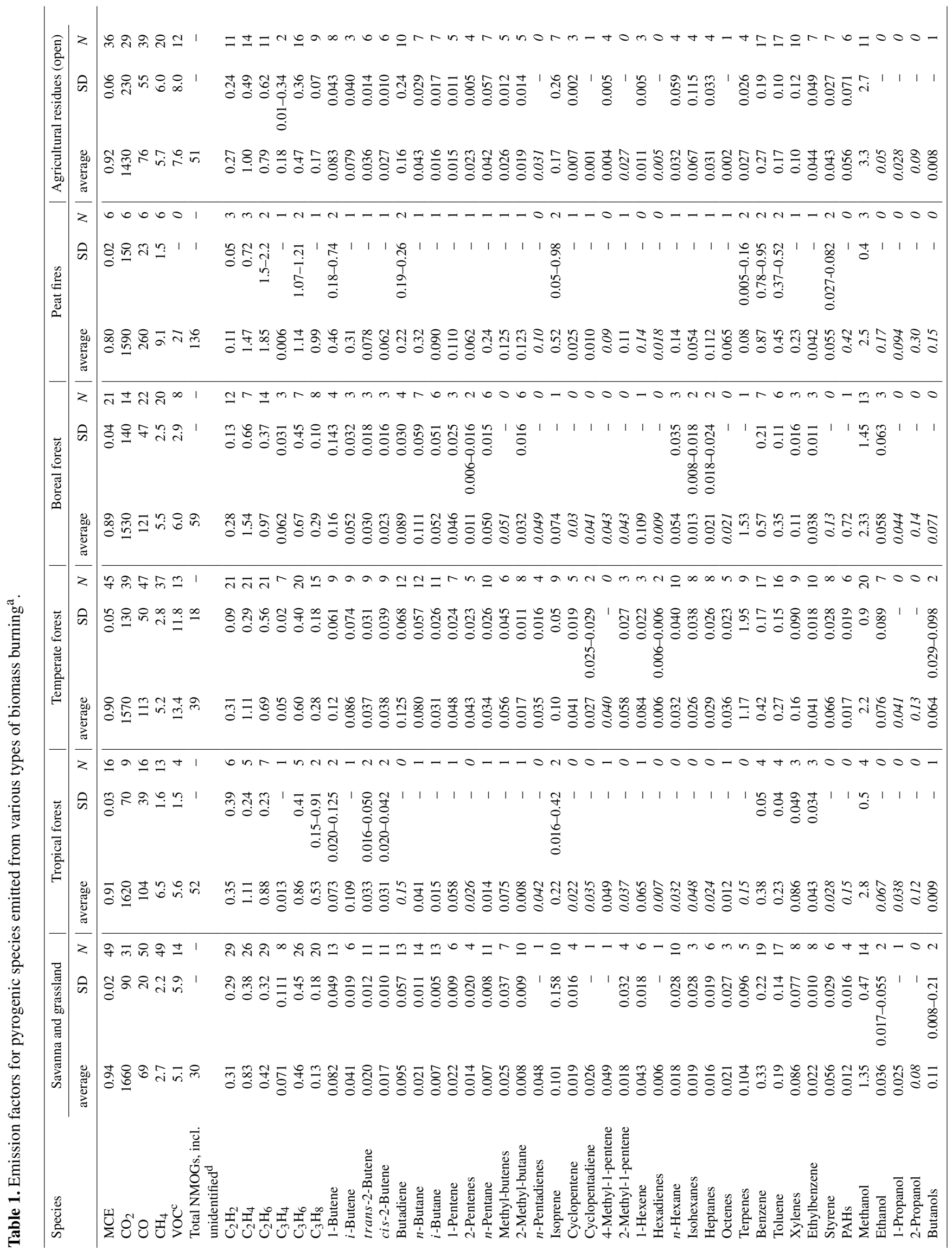



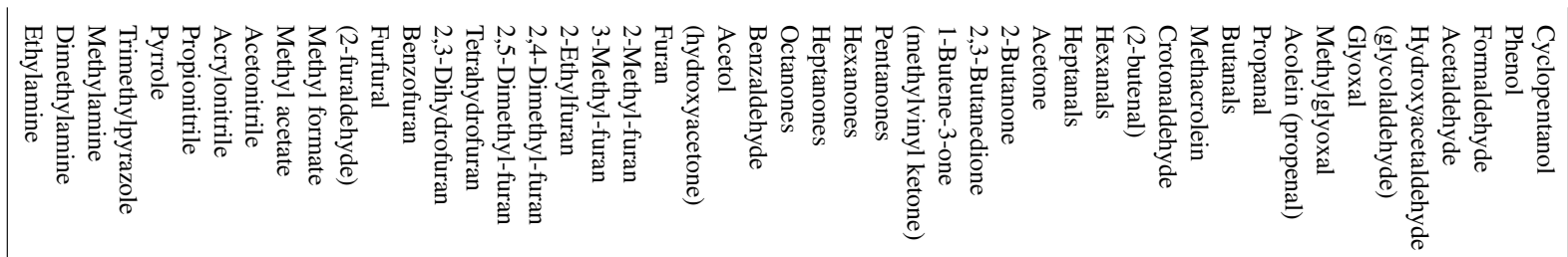

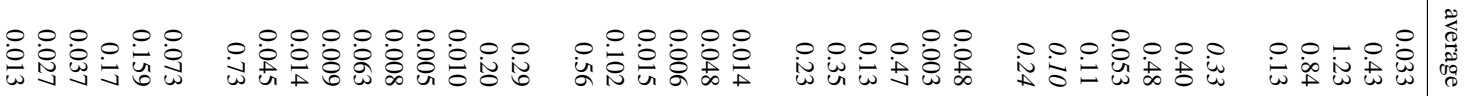

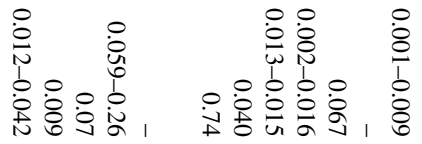

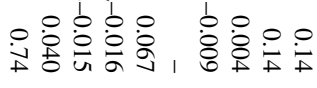

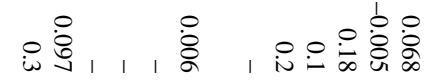

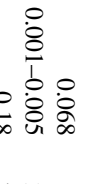

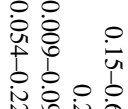

o000-nmon-

$w \rightarrow n N D-N \omega a \infty$

$\omega+---\omega$

$-+a \vee N \omega$

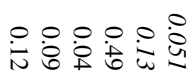

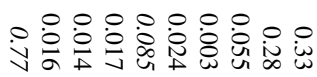

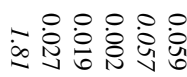

$\circ 00000$

完完家

onnano ubav-

$-----N$

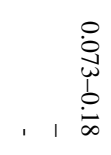

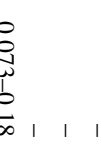

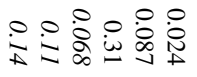

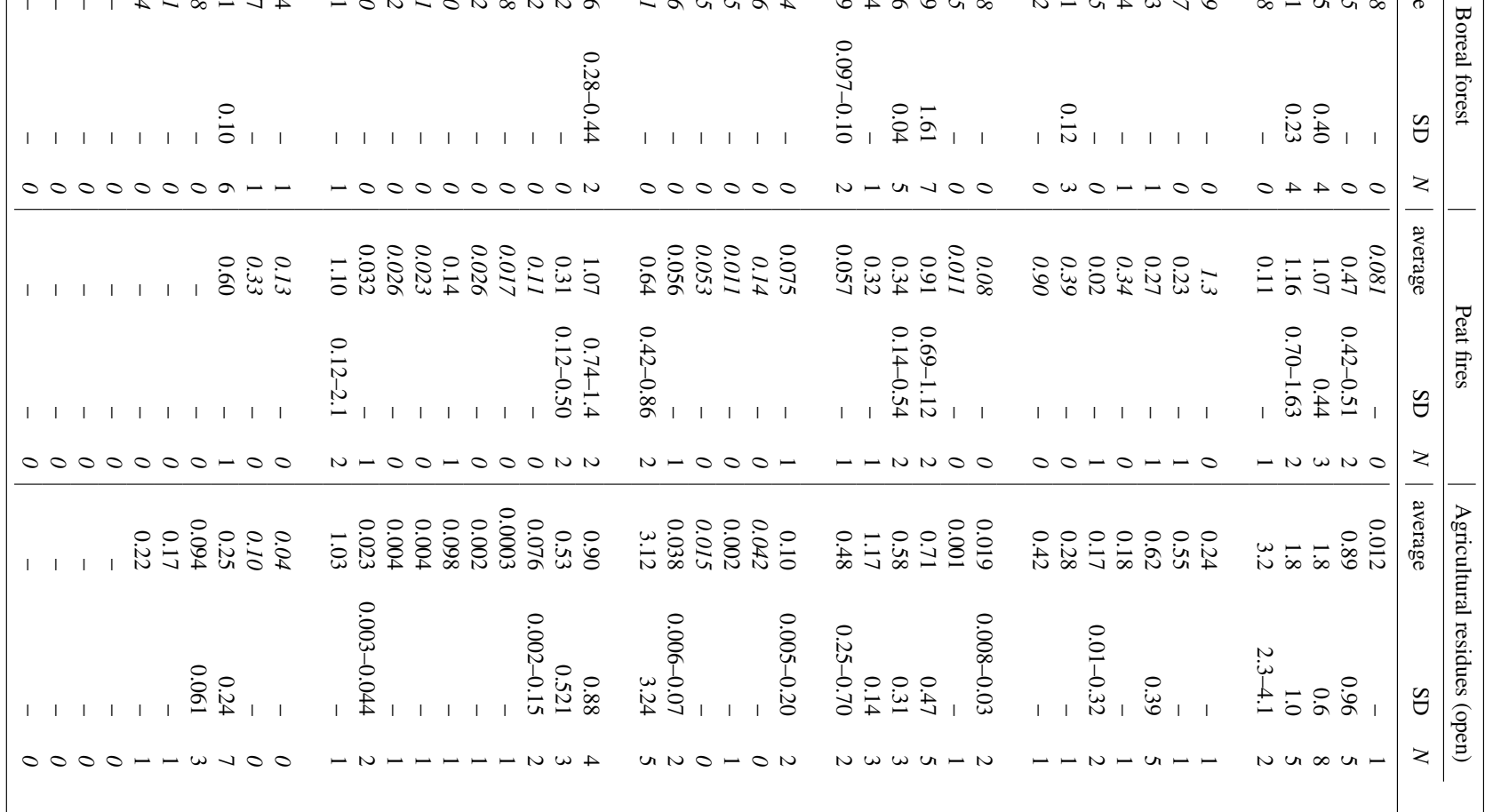




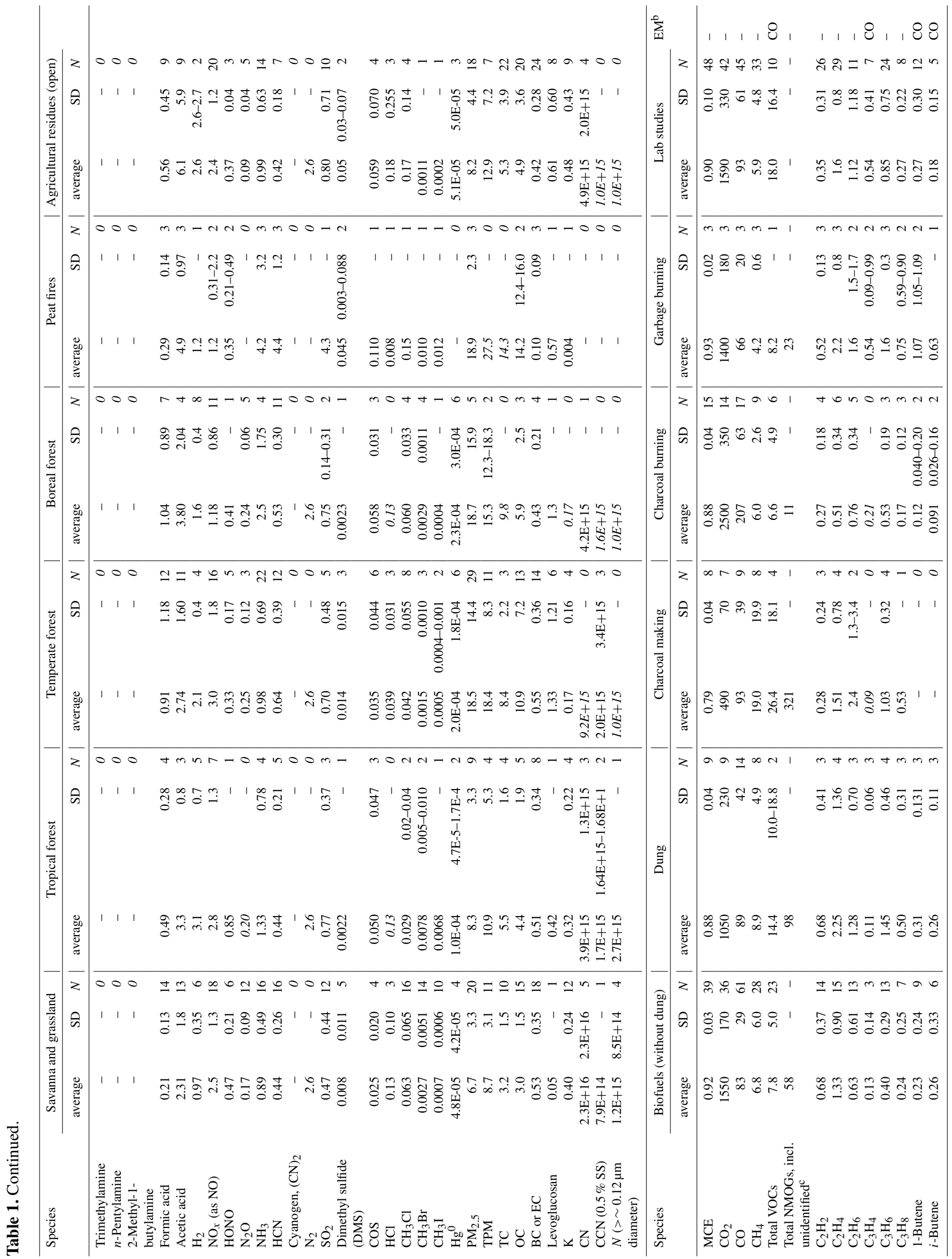




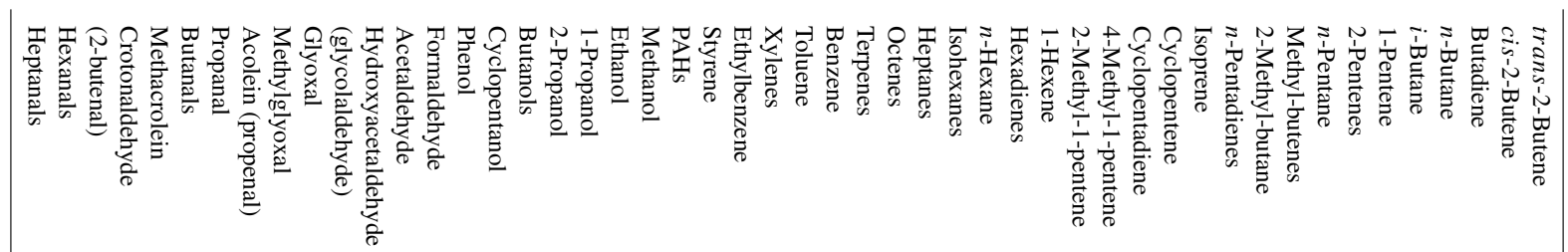

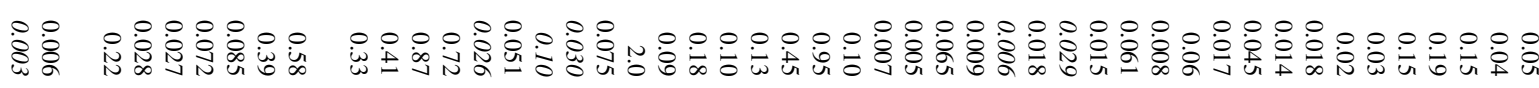

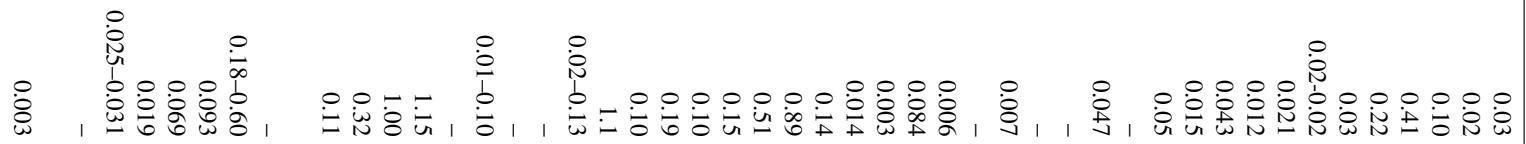

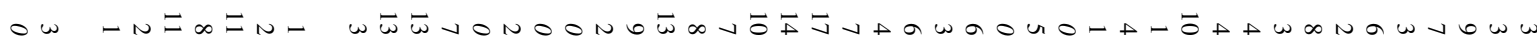

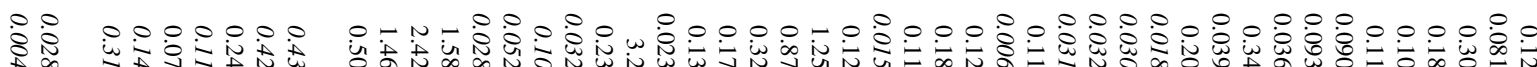

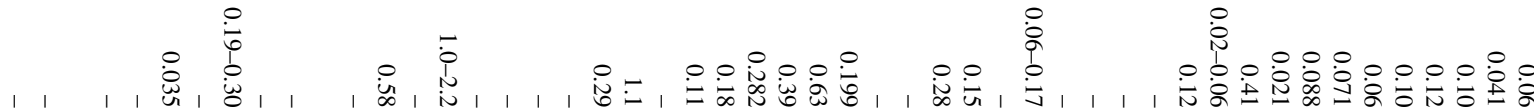

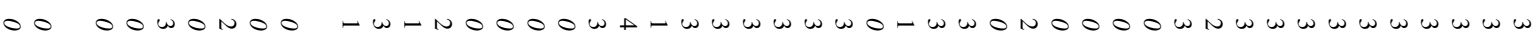

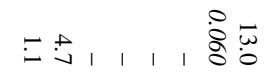<smiles>[Na]O[Hg]</smiles>

$00000000000-100000100000000000000000000000000000$

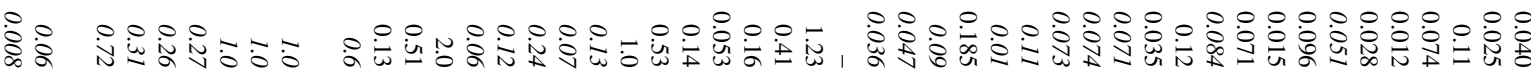

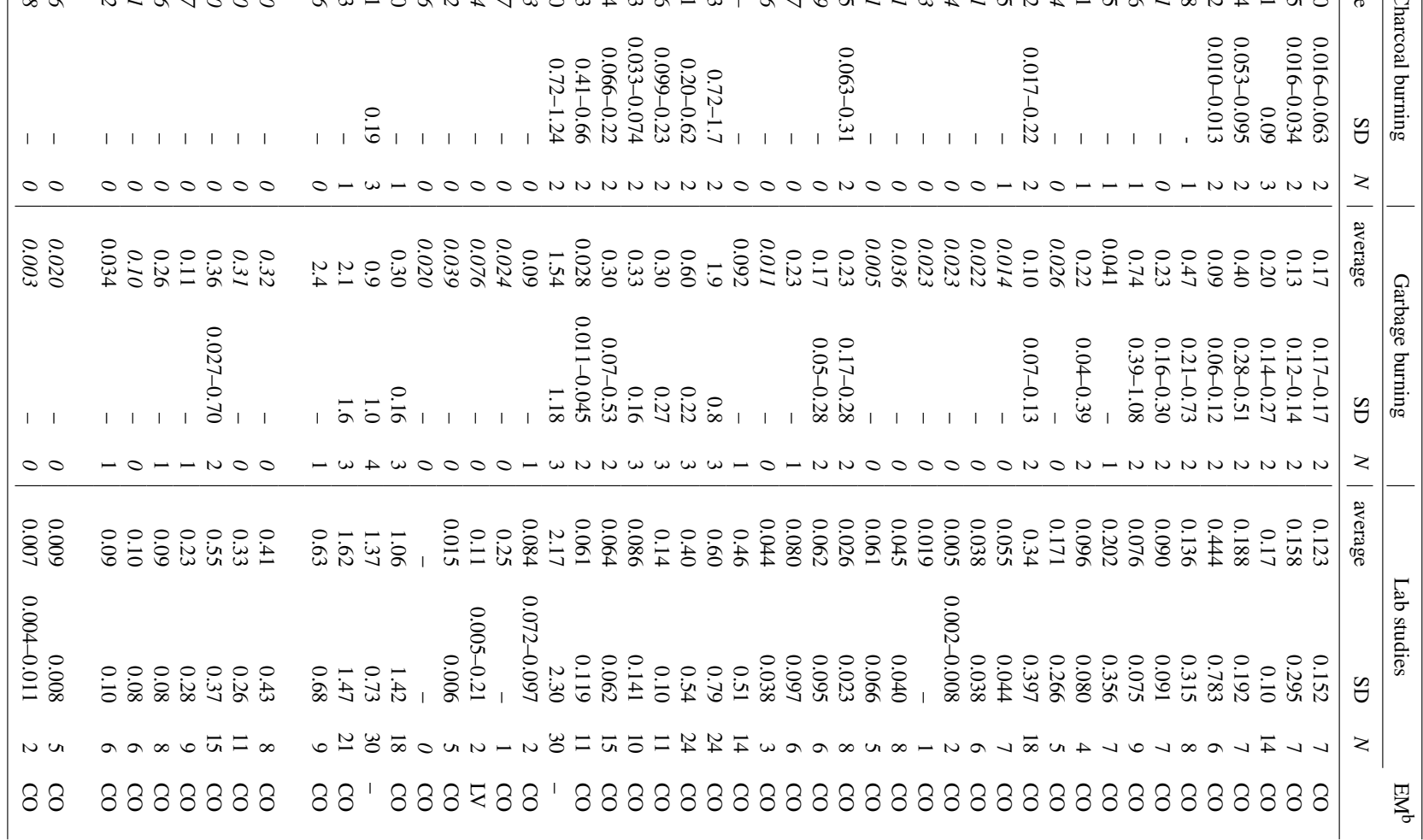




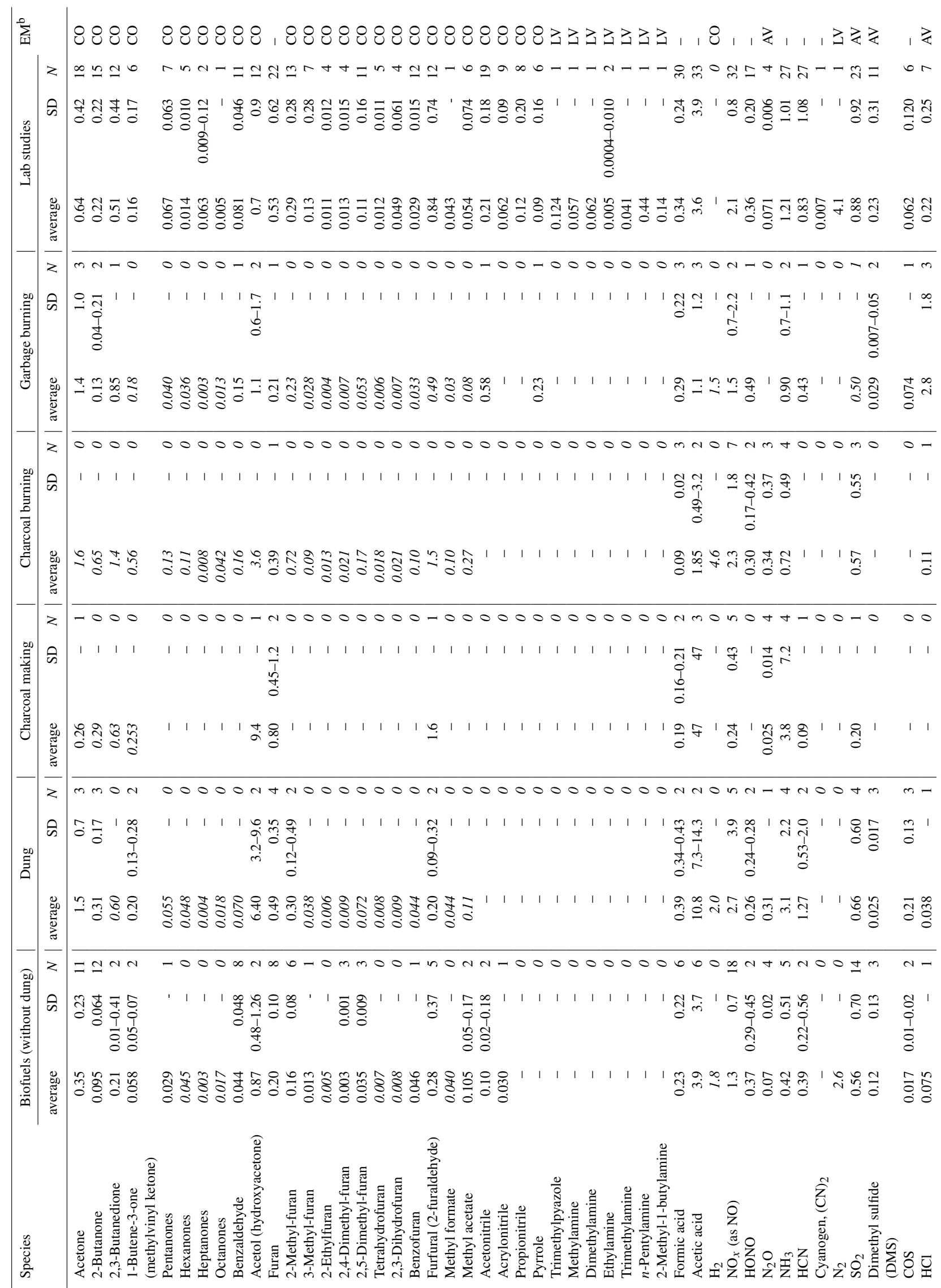




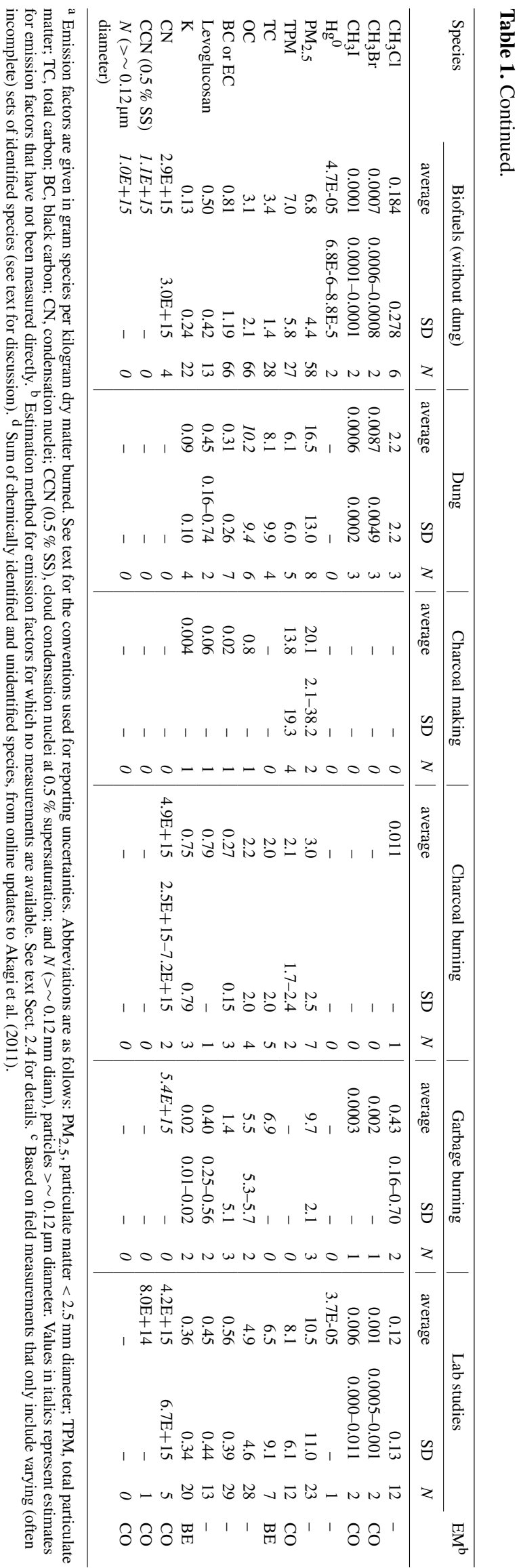

involving transport times and reaction rates of the species concerned. Because of their large spatial and temporal coverage, such measurements are quite valuable, and I have therefore included some of them in this assessment, as long as they were either dealing with long-lived species or used appropriate correction methods (i.e., chemistry-transport model calculations to correct for atmospheric transformations) (Rinsland et al., 2007; Mebust et al., 2011; Tereszchuk et al., 2011, 2013; Schreier et al., 2015; Viatte et al., 2015; Lutsch et al., 2016; Adams et al., 2019). They can be compared with in situ measurement results by referring to the original data in the Supplement spreadsheet.

Another special case are the emission factors for gaseous elemental mercury $\left(\mathrm{Hg}^{0}\right)$. Here, only relatively few actual field emission measurements are available for most of the combustion types listed in Table 1. Therefore, I have followed the approach of Friedli et al. (2009) and included $\mathrm{Hg}^{0}$ emission factors from studies that are based on the $\mathrm{Hg}$ content of the fuels and the assumption of total volatilization of $\mathrm{Hg}$ from the fuel during combustion, which appears well justified for this volatile element.

Generally, the results from laboratory combustion studies have not been included in the emission factor averages for the different fire types in Table 1, but they are given for comparison in a separate column in Table 1 . The reason for this decision is that such experiments often do not reproduce realistic burning conditions in the field. For example, it has been shown that the emissions of many trace gases are strongly dependent on fuel moisture, temperature, wind, and other fire environment parameters (e.g., L.-W. A. Chen et al., 2010; Robertson et al., 2014; Liu et al., 2017; Thompson et al., 2019). The fuels in lab experiments, however, may be well aged and dried and thus have a much lower moisture content than fuels in the field, and the wind conditions in the field are impossible to reproduce in the lab. This can be seen in the values of the modified combustion efficiency (MCE; the ratio of $\left.\Delta \mathrm{CO}_{2} /\left(\Delta \mathrm{CO}_{2}+\Delta \mathrm{CO}\right)\right)$ in many lab studies, which are much higher than those typical of field burns, an extreme example being the study by Sirithian et al. (2018), who reported a mean MCE of 0.9996 in a lab study on biofuel burning. Therefore, lab results are only used in some special cases, where little or no field data are available, and where the lab data appear representative based on their MCE (e.g., Christian et al., 2003) or had been adjusted to reflect field conditions using "overlap species", emission ratios (ERs), or MCE as discussed in Yokelson et al. (2013b). Some lab values are also used as estimates in Table 1; they are shown in italics and indicated as "LV" in the last column.

The studies on emissions from biofuel burning for cooking or heating represent a borderline case, as they are often conducted in a laboratory environment but with an effort to simulate the actual fuel use conditions and stove setups used in households. Here, I have favored studies performed in actual households but also included results from lab studies that appeared to realistically emulate field conditions. Results from 
modern residential biofuel combustion units, such as automated pellet burners or modern low-emission stoves, have not been included. A more detailed analysis of emissions from different types of domestic biofuel use can be found in Akagi et al. (2011), albeit without the benefit of the numerous papers that have been published on these emissions in the last decade. A special review on this issue would be desirable but is beyond the scope of this paper.

In contrast to gaseous compounds, which are chemically well defined, aerosols are complex and variable mixtures of organic and inorganic species and comprise particles across a wide range of sizes. This affects in particular the measurements of organic aerosol, black/elemental carbon, and sizefractionated aerosol mass. Organic aerosol is usually measured either by a variety of thermochemical or mass spectrometric methods, both of which may have positive and negative artifacts, for which different authors have applied different corrections. Since some techniques report the result as organic aerosol mass and others as organic carbon mass concentrations, a conversion had to be applied. To convert between organic carbon and organic matter (OM), a default $\mathrm{OM} / \mathrm{OC}$ mass ratio of 1.6 is used in the absence of specific information. This value is based on the data from fresh biomass smoke aerosol in the literature (Turpin and Lim, 2001; Aiken et al., 2008; Yokelson et al., 2009; Takahama et al., 2011; Kostenidou et al., 2013; Brito et al., 2014; Collier et al., 2016; Fang et al., 2017; Tkacik et al., 2017; Ahern et al., 2019; Lim et al., 2019). Where only O/C ratios were given, they were converted to $\mathrm{OM} / \mathrm{OC}$ ratios using the relationship given in Aiken et al. (2008).

Black carbon (BC) and elemental carbon (EC) are an even more problematic category. Various definitions for these species have been used (Andreae and Gelencsér, 2006), but most commonly $\mathrm{BC}$ refers to carbon with specific optical properties (light absorption) and is measured by optical techniques, whereas EC is defined by its chemical properties and determined by a variety of thermochemical methods. Not all authors, however, adhere to these definitions, and the terms soot, EC, and BC are often used interchangeably. Unfortunately, while some techniques have been shown to have less bias than others (H. Y. Li et al., 2019), there is no general answer as to which technique is best, and which property, optical or chemical, is more representative. In view of the lack of a better alternative, both BC and EC data have been merged in the "BC" category here.

The size distribution of biomass smoke aerosols is a continuum ranging from tens of nanometers to millimeters (Reid et al., 2005), with most of the mass present in a mode at a few hundred nanometers. Mass concentration measurements are typically reported as $\mathrm{PM}_{1}, \mathrm{PM}_{2.5}, \mathrm{PM}_{10}$, or TPM, referring to the size ranges below $1,2.5$, and $10 \mu \mathrm{m}$, and total mass, respectively. For convenience, data reported as $\mathrm{PM}_{1}$ and $\mathrm{PM}_{2.5}$ have been grouped together in the $\mathrm{PM}_{2.5}$ category, which in view of the typical biomass burning (BB) aerosol size distribution is not expected to result in significant bias. The same applies to the $\mathrm{PM}_{10}$ and TPM data, which were grouped together in the TPM category.

Emission data for ionic species and trace metals are not included in this data set. They are tabulated in Akagi et al. (2011), and additional information can be found in a number of papers (e.g., Goetz et al., 2018; Jayarathne et al., 2018a, b).

Another problematic "species" is the total concentration of non-methane organic gases (NMOGs), also referred to as volatile organic compounds (VOCs). The diverse methods used for these compounds measure different sets of NMOGs, which in some instances may be quite incomplete. In general, the more recent studies from the last 5-7 years are much more comprehensive and show that the early studies were severely underestimating the amounts of NMOGs emitted. Regrettably, these new techniques have been so far used mostly in lab studies and could therefore not be considered for the combustion category emission estimates. To highlight this issue, I have added the NMOG emission factors from the online updates to Akagi et al. (2011) in Tables 1 and 3.

\subsection{Definitions}

In the literature, emission information is generally found as either emission ratios (ERs) or emission factors (EFs). Strictly speaking, most data presented as "emission ratios" are actually enhancement ratios (EnR), often also referred to as normalized excess mixing ratios (NEMRs; Akagi et al., 2011). They are defined as the ratio of the excess mixing ratio of the species of interest in the plume, $(\Delta X)$, to the excess mixing ratio of a reference species, e.g., carbon monoxide $(\triangle \mathrm{CO})$ :

$\operatorname{EnR}_{X / \mathrm{CO}}=\frac{\Delta X}{\Delta \mathrm{CO}}=\frac{(X)_{\text {plume }}-(X)_{\text {backgr }}}{(\mathrm{CO})_{\text {plume }}-(\mathrm{CO})_{\text {backgr }}}$,

where $\Delta$ stands for the difference between the mixing ratio in the plume and in the background atmosphere (in molar units). Because of its abundance in fire emissions and its relatively low ambient background concentration, $\mathrm{CO}$ is most commonly used as reference species, but other gases, such as carbon dioxide $\left(\mathrm{CO}_{2}\right)$, methane $\left(\mathrm{CH}_{4}\right)$, or acetonitrile have also been used. The use of $\mathrm{CO}_{2}$ can introduce large errors because it also has strong surface sources and sinks, which can lead to erroneous estimates of the background concentration, as discussed in detail in Yokelson et al. (2013a). A statistical method using multiple fire tracers (Mixed Effects Regression Emission Technique, MERET), which can resolve the problems associated with variable $\mathrm{CO}_{2}$ background concentrations, has recently been developed (Chatfield et al., 2019).

An enhancement ratio can be interpreted as an emission ratio when it is assured that the concentrations of both species $\mathrm{X}$ and the reference species have not been affected by chemical production or loss since the emission and that both concentrations have changed proportionally during dilution of the plume with background air. In the case of very long-lived 
substances, e.g., acetonitrile, EnRs can be very close to ERs even after days, while for reactive compounds, e.g., nitric oxide (NO), significant changes can occur in minutes. For very rapidly reacting species, it becomes difficult to define an appropriate time after emission at which an EnR can be treated as an effective ER. A good example is the emission of primary organic aerosol mass, whereby the apparent EnR decreases substantially (by about a factor of 2) over the first few minutes to hours as a result of the evaporation of semivolatile compounds during plume dilution (May et al., 2013; Konovalov et al., 2019). Whether the ER at the moment of emission or the EnR after cooling and dilution to typical ambient conditions is the more meaningful value will depend on the intended application. In general, field measurements are likely to represent somewhat more aged conditions (tens of minutes to a few hours), whereas lab measurements often represent very fresh emissions. For further discussion of the advantages and disadvantages of the different reference gases, the effects of flaming vs. smoldering combustion, and ground-based vs. airborne sampling, see A\&M2001, Burling et al. (2011), and Akagi et al. (2011).

While the measurement of ERs is relatively straightforward in the field, because it requires only the measurement of the atmospheric concentrations of target and reference species, it is generally desirable to obtain the amount of a species emitted per unit mass of fuel burned, i.e., the emission factor, EF. For biomass burning, this is usually expressed as the mass of target species $X$ released per mass of dry fuel burned, in units of grams per kilogram $\left(\mathrm{g} \mathrm{kg}^{-1}\right)$. This, however, requires knowledge of the mass of fuel burned, which can easily be measured in the lab but is difficult to obtain in the field. As an alternative, the mass balance method can be used, whereby the mass of fuel burned is approximated by the sum of carbon contained in the emitted carbon species $\left(\mathrm{CO}_{2}, \mathrm{CO}, \mathrm{CH}_{4}\right.$, volatile organic compounds (VOCs), organic aerosol carbon (OC), and elemental carbon (EC) or black carbon (BC)), divided by the carbon fraction in the fuel. Often, the carbon mass is approximated by the sum of $\mathrm{CO}_{2}$ and $\mathrm{CO}$, and a default fuel carbon content of $45 \%$ is assumed.

To provide a uniform representation of the various types of data found in the literature in the form most useful to modelers, all emission data were converted to emission factors, in units of grams per kilogram $\left(\mathrm{g} \mathrm{kg}^{-1}\right)$ of dry fuel burned. Where emission factors relative to other fuel mass indicators were given, e.g., the mass of carbon burned or released, I applied appropriate conversion factors, such as the known or assumed carbon content of the fuel. Very frequently in the literature, only EnRs or ERs in units of mole / mole are provided. These can in principle be easily converted to EFs by the following equation:

$\mathrm{EF}_{X}=\mathrm{ER}_{(X / Y)} \frac{\mathrm{MW}_{X}}{\mathrm{MW}_{Y}} \mathrm{EF}_{Y}$, where $\mathrm{EF}_{X}$ is the emission factor for species $X, \mathrm{ER}_{(X / Y)}$ is the emission ratio of species $X$ relative to the reference species $Y, \mathrm{MW}_{X}$ and $\mathrm{MW}_{Y}$ are the molecular weights of the species $X$ and the reference species $Y$, and $\mathrm{EF}_{Y}$ is the known or assumed emission factor of the reference species (often $\mathrm{CO}$ or $\mathrm{CH}_{4}$ ). When the value of $\mathrm{EF}_{Y}$ was not known for a specific study, the mean $\mathrm{EF}_{Y}$ for the appropriate type of fire (forest, savanna, etc.) was applied to derive an estimate of $\mathrm{EF}_{X}$.

\subsection{Estimates for which no data are available}

For some combinations of fire type and emitted species, no suitable field data are available to provide a basis for estimating EFs. Where possible, I have used appropriate methods to derive estimates (shown in italic font in Table 1) based on other information. For each species, the estimation method is given in column EM. For species predominantly emitted during smoldering combustion, e.g., most VOCs, I have based the estimate on the assumption that their emission factors for the various fire categories are proportional to those of $\mathrm{CO}$ for the same categories. The estimate was then obtained by calculating the mean of the ratios $\mathrm{EF}_{X} / \mathrm{EF}_{\mathrm{CO}}$ for the fire categories with available data and multiplying this mean ratio by the $\mathrm{EF}_{\mathrm{CO}}$ of the fire category for which an estimate was needed (labeled CO in column EM). Where no suitable ratios $\mathrm{ER}_{X} / \mathrm{ER}_{\mathrm{CO}}$ were available from field studies, the lab ratio was used instead (labeled LV). For some species containing heteroelements $\left(\mathrm{N}_{2} \mathrm{O}, \mathrm{SO}_{2}\right.$, DMS, and $\left.\mathrm{HCl}\right)$, the mean of the ERs from fire categories with available data, weighted by the amounts of biomass globally burned in those categories, was used (labeled AV). Subjective "best estimates" are labeled BE. Specifically, for missing values of total particulate carbon emissions, the sum of OC and EC emissions was used, and for aerosol potassium emissions in boreal forest fires I used the temperate forest value.

\section{Results and discussion}

\subsection{Combustion process and pyrogenic emissions}

Our fundamental understanding of the biomass combustion process has remained unchanged since the 1990s, as reviewed in A\&M2001 and other papers (Lobert and Warnatz, 1993; Yokelson et al., 1996, 1997; Akagi et al., 2011) and will thus be summarized here only briefly. As the flaming or glowing front of a fire moves towards the uncombusted fuel, the fuel is heated by radiative and sensible heat transfer, leading first to evaporation of water and other volatiles, then to pyrolytic decomposition and the release of volatile and semivolatile (tar) decomposition products (Collard and Blin, 2014). When this released mixture ignites, flame chemistry sets in, which breaks down the more complex pyrolysis compounds to small molecules and radicals but also produces new larger molecules by radical chemistry, such 
as alkynes, polycyclic aromatic hydrocarbons (PAHs), soot, and organohalides. In addition to volatile matter being consumed by flaming combustion, char undergoes gas-solid reactions between oxygen and other gases and solid carbon at the fuel surface, called gasification or "glowing" combustion, in which a large fraction of the fuel carbon is released as $\mathrm{CO}$, part of which is further oxidized to $\mathrm{CO}_{2}$. In a typical vegetation fire, all these processes occur simultaneously as the fire propagates through the fuel, so that the fire plumes at any place and time contain mixtures of flaming and smoldering (vernacular for a changing mix of distillation, pyrolysis, and glowing) combustion products in variable proportions.

Depending on the vegetation type and burning conditions, the relative amounts of fuel consumed by flaming and smoldering combustion can vary considerably. Dry grassland fires, for example, are dominated by flaming combustion and a rapid passage of the fire front, with little residual smoldering. Forest fires, on the other hand, especially those in fuels with relatively high fuel moisture and large diameters, have a long phase of residual smoldering combustion (RSC), during which larger-diameter fuels are consumed over time spans of up to several days (Ward and Hardy, 1991; Ward et al., 1992; Yokelson et al., 1997; Bertschi et al., 2003; Hao and Babbitt, 2007; Burling et al., 2011; Akagi et al., 2013; Geron and Hays, 2013; Urbanski, 2014; Reisen et al., 2018). The smoldering mode of combustion can become dominant in peat fires, which often proceed without a flaming phase and below ground (Bertschi et al., 2003; Stockwell et al., 2016b).

Since the rate of heat release during RSC is relatively low, and much of it occurs during nighttime, the resulting emissions tend to accumulate close to the ground in the boundary layer. At nighttime, emissions are confined in a nocturnal boundary layer, often less than $100 \mathrm{~m}$ thick, where the fire-emitted $\mathrm{CO}_{2}$ becomes mixed with $\mathrm{CO}_{2}$ from biological respiration. This presents serious problems for measuring accurate and representative fire-integrated emission factors for fires where RSC emissions are important (Bertschi et al., 2003). Ground-based studies during the RSC phase can obtain ERs of trace species, but these are difficult to relate to the corresponding amount of fuel burned. Aircraft studies have trouble measuring the RSC component of these emissions, as they are not lofted in the form of discrete plumes to aircraft altitudes but only mixed upward during daytime convection (or fire blow-ups) where they get distorted by mixing in the ambient atmosphere (Guyon et al., 2005). The mixing of biogenic and pyrogenic $\mathrm{CO}_{2}$ in fire plumes that entrain such boundary layer air into a deeper mixed layer presents serious problems for deriving fire-integrated ERs and EFs from aircraft measurements (Yokelson et al., 2013a), which can potentially be addressed by the multi-tracer MERET approach (Chatfield et al., 2019).

Because the flaming phase is characterized by $\mathrm{CO}_{2}$ being the dominant combustion product by far, while the smoldering phase yields relatively large amounts of $\mathrm{CO}$ (up to about $30 \%$ of carbon burned), the MCE has been established over
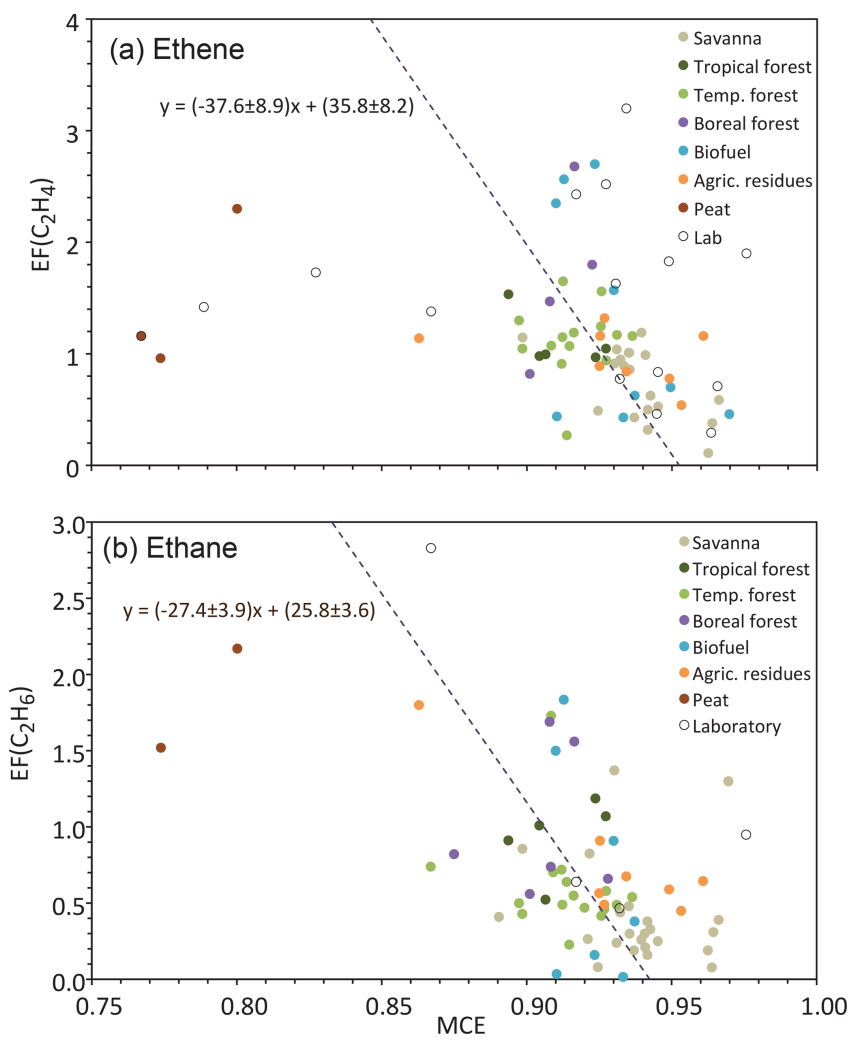

Figure 1. Scatter plots of the emission factors of ethene (a) and ethane (b) against MCE, based on studies in the different combustion categories.

the last two decades as the key metric representing the relative role of flaming vs. smoldering combustion in vegetation fires, spanning a range of 0.77 in peat fires to 0.98 in some grassland fires (see Supplement). Mean MCE values for the different combustion categories are presented in Table 1.

Since the MCE was introduced by Ward and Radke (1993), numerous papers have used this metric and have shown significant negative correlations for many trace gases between emission factors and MCE, especially for the various VOCs that are emitted predominantly during smoldering combustion (e.g., Korontzi et al., 2003; Yokelson et al., 2003, 2008, 2013b; Soares Neto et al., 2009; Urbanski et al., 2009; Burling et al., 2011; Urbanski, 2013, 2014; Liu et al., 2014; Collier et al., 2016; Coffey et al., 2017; Fortner et al., 2018; Hodgson et al., 2018; Reisen et al., 2018; Jen et al., 2019). However, the correlation slopes between EFs and MCE vary considerably between studies in different fuels and burning environments, so that a global parameterization of all EFs based on observed or modeled MCE remains problematic. As an illustration, I show in Fig. 1a and $1 \mathrm{~b}$ plots of the EFs of ethene $\left(\mathrm{C}_{2} \mathrm{H}_{4}\right)$ and ethane $\left(\mathrm{C}_{2} \mathrm{H}_{6}\right)$ vs. $\mathrm{MCE}$, based on the average values from the individual studies in the supplemental spreadsheet. In both cases, the results scatter widely, and especially the data from the lab 
studies, biofuel burning, peat fires, and RSC-dominated fires introduce a large amount of scatter. The limitations in correlation between EFs and MCE have been noted previously (Yokelson et al., 1997; Bertschi et al., 2003; Burling et al., 2011; Urbanski, 2014). In the case of ethene, the correlation using all data points is not significant $\left(R^{2}=0.07\right)$. However, when only the data from open vegetation fires are included (and after removing three outliers), the correlation improves to an $R^{2}$ of 0.27 . For ethane, the correlation coefficient is $R^{2}=0.38$ for all data but does not improve substantially by removing the peat fire data. These results suggest that the level of aggregation at which MCE is useful as a meaningful but rough predictor of EFs for at least some species is yet to be determined. This approach is not pursued further here, but the data in the original studies listed in the Supplement can be used by investigators to derive such relationships for specific compounds and combustion types of interest. An interesting and novel approach to generalizing VOC emissions is provided by Sekimoto et al. (2018), who showed that most of the variability in VOC emissions measured in a lab study using a wide variety of fuels was explained by just two factors, related to low and high temperature pyrolysis, respectively.

Using MCE as a predictor variable may be an alternative to providing separate EFs for smoldering and flaming combustion, which has been frequently requested by the modeling community but for which there are still not enough data to provide robust estimates, as we already remarked previously in A\&M2001. However, once vegetation fire models are able to provide estimates of the contribution of flaming and smoldering combustion from a given fire, the resulting MCE could be predicted. This could then form the basis of a more fire-specific prediction of trace gas and aerosol emissions based on MCE correlations. An alternative approach was proposed by Hoffa et al. (1999) and further developed by Korontzi et al. (2003), who showed a correlation between vegetation greenness and MCE, which allowed the prediction of seasonally dependent emissions from African savanna fires (Ito and Penner, 2004; Korontzi et al., 2004; Korontzi, 2005). In view of the limitations seen with regard to more general parameterizations, it appears that for now one can keep using the category-average EFs, but be aware they can vary considerably from region to region and from fire to fire.

\subsection{Emission factors for chemical species from the various combustion categories}

In Table 1, I present the updated estimates of emission factors for the combustion categories, savanna and grassland, tropical forest, temperate forest, boreal forest, peat fires, open agricultural waste burning (in the fields), biofuels (excluding dung), dung cakes, charcoal making, charcoal burning, and garbage burning. As more data have become available, it was now possible to split the extratropical forest category into temperate and boreal forest burning. The transition be- tween these two types is not always clear, but in general, I have followed the authors' choice of category; where this was not possible I have taken a latitude of $60^{\circ} \mathrm{N}$ as a boundary.

The large number of studies on residential biomass burning, which have been published in the last two decades, has made it possible to separate dung cakes from the other biofuels, such as fuel wood and agricultural residues. As mentioned above, I only included studies that used fireplaces and traditional or simple "improved" stoves, as are used in developing countries, and not modern appliances, such as automated pellet stoves.

The publication of a few papers that provide emissions data for open garbage burning, still quite prevalent in many countries and a serious source of pollution especially in urban areas (Wiedinmyer et al., 2014), has made it possible to provide EFs for this category.

Obviously, the categories used here are still quite highly aggregated, but they correspond closely to the fire types used in many global modeling studies, such as those involved in the Fire Modeling Intercomparison Project (FireMIP) (F. Li et al., 2019) and in model- or satellite-based emission inventories (Wiedinmyer et al., 2011; Kaiser et al., 2012; Ichoku and Ellison, 2014; Darmenov and da Silva, 2015; van der Werf et al., 2017). Should a reader require less highly aggregated data, they can use the Supplement to split the data into subcategories or even use the supplemental references to get back to the original literature. Valuable detail about the various burning types and further breakdown of some categories, e.g., biofuel use, into relevant subcategories can be found in Akagi et al. (2011).

For information purposes, I also include a column summarizing the results of laboratory studies. The averages in this column can only be seen as general indication of the magnitude of emission factors found in the lab studies, since all types of fuels and burning methods are included in the statistics presented here. However, the original data and references are provided in the Supplement for readers interested in the details.

As in A\&M2001 and in Akagi et al. (2011), the amount of information for any given combination of species and fire category varies greatly - for some combinations we have no measurements at all, and for others there are as many as $\mathbf{5 0}$ values. Accordingly, the uncertainty of the estimates is also highly variable. In Table 1, I am using the same convention as in A\&M2001 to represent the uncertainty: when three or more values (based on independent references) are available for a given table cell, the results are given as means and standard deviations $(x \pm s)$. In the case of two available measurements, they are given as a range, and where only a single measurement is available, it is given without an uncertainty estimate. For single measurements, it can usually be assumed that the uncertainty is no less than a factor of 3.

In spite of the fact that this paper is based on data from over 370 publications, rather than the 130 papers that formed the basis for A\&M2001, Table 1 shows that there are still 
many species for which there are little or no field data available. For example, there are still no field measurements of the emission factors for the alkyl amines, which have recently become implicated in aerosol nucleation and new particle formation (Smith et al., 2010; Almeida et al., 2013; Kürten et al., 2014). In view of the importance of the number concentrations of aerosol particles $(\mathrm{CN})$, especially cloud condensation nuclei $(\mathrm{CCN})$, for climate change, it is unfortunate that there have only been a few additional measurements of their emission factors in the last two decades. The rapid coagulation of particles very near the source makes it difficult to choose the most appropriate plume age for such a measurement (Hobbs et al., 2003; Sakamoto et al., 2016; Hodshire et al., 2019). However, a survey of available measurements suggests that the ratio of excess particle number concentration ( $\triangle \mathrm{CN}$ or $\triangle \mathrm{CCN}$ ) to $\Delta \mathrm{CO}$ stabilizes at the scale of typical aircraft measurements in plumes, as a consequence of the sharp decrease of the coagulation rate with increasing dilution (Janhäll et al., 2010). More field studies on the evolution of aerosol number concentrations and size distributions as a function of plume age under different conditions (fire size, wind speed, flux density, etc.) are warranted.

Another climate-relevant component, for which we have no field emission data at this time, is brown carbon $(\mathrm{BrC})$ (Andreae and Gelencsér, 2006), which has been shown to account for about half of the aerosol light absorption by biomass smoke at $401 \mathrm{~nm}$ (Selimovic et al., 2019) and $25 \%-$ $45 \%$ at $550 \mathrm{~nm}$ (Tian et al., 2019). Providing EFs for this species is problematic because of the very complex and variable mixture of compounds that make up $\mathrm{BrC}$, as well as its potential for rapid change in abundance and optical properties during plume evolution (Forrister et al., 2015; Fleming et al., 2019). To some extent, data on the optical properties of BB aerosols can substitute direct measurements of $\mathrm{BrC}$ (Stockwell et al., 2016a, b; Goetz et al., 2018; Selimovic et al., 2018).

Regarding the role of vegetation fires in the global carbon cycle, the most problematic uncertainty pertains to the emission factors of $\mathrm{CO}_{2}$ and $\mathrm{CO}$ from forest fires, which is surprising in view of the many available estimates. This uncertainty stems from the inadequate knowledge of the contribution from RSC, which has already been referred to above, and which may significantly contribute to large mismatches between bottom-up predictions of $\mathrm{CO}$ emissions and remotesensing measurements from satellite (Pechony et al., 2013; Deeter et al., 2016). A representative measurement of fireaverage $\Delta \mathrm{CO} / \Delta \mathrm{CO}_{2}$ emission ratios from large forest fires is very difficult if not impossible, as ground-based measurements in such violent fires are not possible, and aircraft measurements are prone to undersampling the smoldering emissions, especially the contributions from RSC. The uncertainty regarding the $\Delta \mathrm{CO} / \Delta \mathrm{CO}_{2}$ emission ratio also seriously hampers our ability to separate the influence of the emissions from deforestation burning from those of biological carbon fluxes in regional carbon budgets (Andreae et al.,
2012). For example, the uncertainty of the $\Delta \mathrm{CO} / \Delta \mathrm{CO}_{2}$ ratios of tropical forest burning is large enough that it can even change the inferred sign of the net carbon flux between the Amazon forest and the atmosphere (Gatti et al., 2014). A novel multi-tracer statistical technique (MERET; Chatfield et al., 2019) may be able to provide improved estimates of the CO ERs and EFs from such fires.

Figure 2 presents a comparison between selected EFs from this study with those published in Akagi et al. (2011) in the form of ratios between the EFs from these studies. For this comparison, I have selected species that are of major climatic or chemical significance or are important BB tracers, and for which there are enough data to allow a meaningful comparison. Data are presented for the combustion types with the largest total global emissions, i.e., savanna and grassland, tropical, temperate, and boreal fires, and biofuel use. In the case of biofuel use, the comparison is made with Akagi et al.'s "open cooking" category because its MCE shows good agreement with that for the "biofuel use" category in this paper. Figure 2 shows close agreement for the main carbon species $\mathrm{CO}_{2}$ and $\mathrm{CO}$ as well as for MCE, suggesting that the averages derived for both species capture comparable combustion conditions. For most other species, the EF ratios fall within a factor of 2 , with no obvious systematic shift for either the individual species or for the combustion types. A slight exception are the EFs for savanna and grassland, which tend to be somewhat higher in the present study. In one case (isoprene) this is the result of higher values from an individual study, i.e., the lab-adjusted-to-field EFs from Stockwell et al. (2015), but generally the differences appear to be the result of including a larger set of studies from this category in the present study. The lower EFs for glycolaldehyde in this study are the result of corrections made by the Yokelson group to their data based on improved spectral data (see https://www.atmos-chem-phys-discuss.net/12/C11864/ 2013/acpd-12-C11864-2013.pdf, last access: 27 June 2019), which have been incorporated here and in the online updates to Akagi et al. (2011), but for consistency the values from the original paper were used for Fig. 2. The largest and most systematic difference is seen for the NMOG category, where the values from Akagi et al. (2011) are as much as a factor of 10 higher than the averages from the published field studies in Table 1. This is largely due to differences in the analytical techniques used in the original studies. Most of the older studies, especially in field campaigns, were measuring only a very limited subset of NMOGs (e.g., non-methane hydrocarbons), whereas Akagi et al. (2011) in the original paper and in the subsequent updates used techniques that measured practically all NMOGs, including unidentified species. To address this issue, I am including both the field study averages (labeled VOCs) and the corresponding values from the online updates to Akagi et al. (2011) (labeled NMOGs) in Table 1 . The latter values may be more appropriate as input for modeling studies that require an estimate of total NMOGs. 


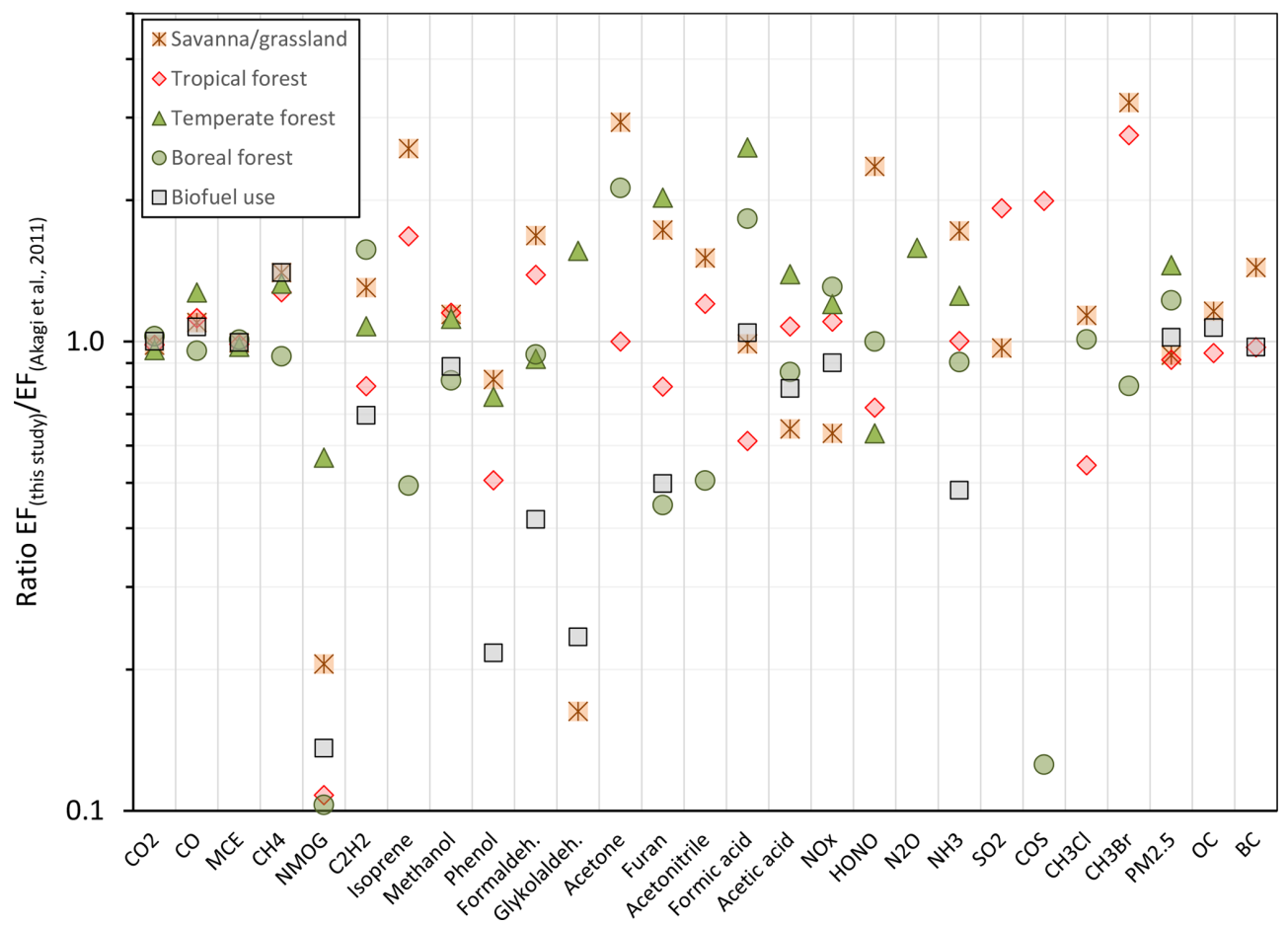

Figure 2. Comparison between the emission factors for selected species between this study and the values in Akagi et al. (2011).

\subsection{Emissions from global biomass burning}

In 2001, we estimated the total amount of biomass burned by all combustion types to be $8.6 \mathrm{Pg}$ dry matter annually, with an uncertainty of $\pm 50 \%$ (A\&M2001). This estimate was based on bottom-up inventories and had not yet benefitted from remote-sensing detection and quantification of fires. At present, there are several operational fire detection and emission estimation products based on remote sensing. Three of them (for example) use an approach based on burned area and hotspot detection: Fire INventory from NCAR (FINN; Wiedinmyer et al., 2011), Fire Locating and Modeling of Burning Emissions (FLAMBE; Reid et al., 2009), and Global Fire Emissions Database (GFED; van der Werf et al., 2017). The other three products are based on fire radiative power (FRP): Quick Fire Emission Dataset (QFED; Darmenov and da Silva, 2015), Global Fire Assimilation System (GFAS; Kaiser et al., 2012), and Fire Energetics and Emissions Research (FEER; Ichoku and Ellison, 2014). The amounts of biomass burned annually in open fires estimated by these systems still span a wide range, from $4.3 \mathrm{Pg}$ (GFAS) to $11.6 \mathrm{Pg}$ (FLAMBE) (for the FRP-based products, which do not use biomass burned in their calculations, the biomass estimate was based on the stated emission of carbon compounds and an assumed carbon fraction of $45 \%$ in the biomass).

For domestic biofuel use, there are three recent global estimates: $2.1 \mathrm{Pg} \mathrm{a}^{-1}$ (Fernandes et al., 2007), $2.5 \mathrm{Pg} \mathrm{a}^{-1}$ (Steven J. Smith, personal communication, 2019, based on the Community Emissions Data System (CEDS) model;
Hoesly et al., 2018), and 2.3 $\mathrm{Pg} \mathrm{a}^{-1}$ (Zbigniew Klimont, personal communication, 2019, based on the methodology in Klimont et al., 2017). These recent estimates are all somewhat lower than those of A\&M2001 (2.9 $\left.\mathrm{Tg} \mathrm{a}^{-1}\right)$ and Yevich and Logan (2003) $\left(3.1 \mathrm{Tg} \mathrm{a}^{-1}\right)$. For charcoal burning, I am also using the estimate of $53 \mathrm{Tg} \mathrm{a}^{-1}$ given for 2014 by FAO Forestry Policy and Resources Division (2015), and for charcoal making I am assuming a $25 \%$ yield of charcoal relative to dry wood (Yevich and Logan, 2003).

Combining these estimates of open and domestic burning yields a mean estimate of $8.8 \mathrm{Pg}$ (with a range of 6.4 to $14.1 \mathrm{Pg}$ ) dry biomass burned annually. Interestingly, this is almost identical to the values given in A\&M2001: 8.6 $\mathrm{Pg} \mathrm{a}^{-1}$, with an estimated range of 4.3 to $12.9 \mathrm{Pg} \mathrm{a}^{-1}$. Table 2 summarizes these emission estimates. For the various categories of open burning, the satellite-derived emission estimates vary greatly, in some cases by an order of magnitude. Differences in the definitions of the burning categories between the different retrieval algorithms, differing ability to detect small fires, and the fundamental difference between the burned-area and FRP-based techniques may all play a role here.

In Table 3, I use the average of the available estimates from the different inventories shown in Table 2 as activity estimates for the combustion categories to derive emission values for major species emitted from biomass burning. For comparison, the last column in Table 3 shows the global total emissions estimated in A\&M2001. The totals of the major emitted carbon species and many minor species remain fairly close to those in our previous assessment. Given the 
Table 2. Estimates of biomass burned (Tg dry matter) annually in the various fire categories.

\begin{tabular}{|c|c|c|c|c|c|c|c|c|}
\hline Source & $\begin{array}{l}\text { Savanna/ } \\
\text { grassland }\end{array}$ & $\begin{array}{r}\text { Tropical } \\
\text { forest }\end{array}$ & $\begin{array}{r}\text { Temperate } \\
\text { forest }\end{array}$ & $\begin{array}{r}\text { Boreal } \\
\text { forest }\end{array}$ & Peat & $\begin{array}{l}\text { Agricultural } \\
\text { residues }\end{array}$ & $\begin{array}{r}\text { Total } \\
\text { open fires }\end{array}$ & Years \\
\hline $\mathrm{FINN}^{\mathrm{a}}$ & 1920 & 3200 & 260 & 137 & - & 210 & 5730 & 2005-2010 \\
\hline GFED $4.1 \mathrm{~s}^{\mathrm{b}}$ & 2980 & 690 & 100 & 330 & 161 & 290 & 4550 & 2005-2015 \\
\hline GFAS $1.2^{\mathrm{c}}$ & 2540 & 910 & 110 & 460 & 183 & 63 & 4260 & 2003-2018 \\
\hline $\mathrm{QFED}^{\mathrm{d}}$ & 3690 & 850 & 280 & 200 & - & - & 5560 & 2003-2012 \\
\hline FEER $^{\mathrm{e}}$ & - & - & - & - & - & - & 9330 & 2000-2012 \\
\hline FLAMBE $^{\mathrm{f}}$ & 870 & 8750 & 750 & 1120 & - & 99 & 11580 & $2005-2015$ \\
\hline ECLIPSE V6a & - & - & - & - & - & 530 & - & 2005-2010 \\
\hline \multirow[t]{2}{*}{ Average } & 2400 & 2880 & 300 & 450 & 172 & 240 & 6440 & \\
\hline & Wood etc. & $\begin{array}{r}\text { Charcoal } \\
\text { making }\end{array}$ & $\begin{array}{r}\text { Charcoal } \\
\text { burning }\end{array}$ & $\begin{array}{r}\text { Agricultural } \\
\text { waste }\end{array}$ & Dung & & $\begin{array}{r}\text { Total } \\
\text { biofuel }\end{array}$ & \\
\hline Fernandes ${ }^{h}$ & 1350 & 156 & 39 & 500 & 75 & & 2120 & 2000 \\
\hline $\mathrm{FAO}^{\mathrm{i}}$ & - & - & 53 & - & - & & - & 2014 \\
\hline ECLIPSE V6a & 1780 & - & 44 & 350 & 89 & & 2270 & 2005-2010 \\
\hline CEDS $^{j}$ & 1590 & - & 46 & 580 & 88 & & 2490 & 2010 \\
\hline Average & 1570 & 180 & 45 & 480 & 84 & & 2360 & \\
\hline \multicolumn{7}{|c|}{ Grand total from all biomass burning } & 8800 & \\
\hline
\end{tabular}

\footnotetext{
${ }^{a}$ Wiedinmyer et al. (2011). ${ }^{\text {b }}$ From http://www.geo.vu.nl/ gwerf/GFED/GFED4/tables/GFED4.1s_C.txt (last access: 27 June 2019 ) assuming 45\% C in biofuel. ${ }^{\mathrm{c}}$ Imke Hüser, personal communication 2019, based on methodology in Kaiser et al. (2012). ${ }^{\mathrm{d}}$ Anton Darmenov, personal communication 2019, based on methodology in Darmenov and da Silva (2015). Emissions from boreal fires were calculated from extratropical fires north of $50^{\circ} \mathrm{N}$, and temperate emissions were calculated by subtracting boreal from extratropical emissions; emissions from crop residue burning fires are included in the grassland fire category. ${ }^{\mathrm{e}}$ Ichoku and Ellison (2014), not included in category averages because breakdown not available. ${ }^{\mathrm{f}}$ Edward Hyer, personal communication 2019 , based on methodology in Reid et al. (2009). Temperate and boreal emissions were calculated by splitting extratropical burning $40 \% / 60 \%$. ${ }^{\mathrm{g}}$ Zbigniew Klimont, personal communication 2019 , based on methodology in Klimont et al. (2017). ${ }^{\mathrm{h}}$ Fernandes et al. (2007). ${ }^{\mathrm{i}}$ FAO Forestry Policy and Resources Division (2015). ${ }^{\mathrm{j}}$ Steven Smith, personal communication 2019, based on methodology in Hoesly et al. (2019).
}

large number of measurements for the emission factors for the major species, $\mathrm{CO}_{2}, \mathrm{CO}$, and $\mathrm{CH}_{4}$, the standard error of the mean is much smaller than the standard deviation, and thus the relative uncertainties of the mean for these emission factors are quite small, $1 \%-3 \%$ for $\mathrm{CO}_{2}, 4 \%-9 \%$ for $\mathrm{CO}$, and $6 \%-18 \%$ for $\mathrm{CH}_{4}$ from the major burning categories savanna, forests, and biofuel. Consequently, the global emission uncertainties for these species are completely dominated by the large uncertainties in the activity estimates.

The best independent "reality check" for these emissions may still come from the inverse modeling of the CO budget. This species is the most appropriate for such a comparison because its emission factors are well constrained, biomass burning is a large fraction of all global sources, and there is a large body of measurements both from ground stations and remote sensing. Estimates of $\mathrm{CO}$ emissions from the various inversion models range from 190 to $560 \mathrm{Tg} \mathrm{a}^{-1}$ from biofuel burning and 360 to $610 \mathrm{Tg} \mathrm{a}^{-1}$ from open burning for the years around 2000 (Park et al., 2015, and references therein). The model of Park et al. (2015), which uses a joint inversion of CO concentrations and oxygen isotopic composition and therefore is likely to be the most reliable in separating the different source types, predicts $\mathrm{CO}$ emissions of 380 to $610 \mathrm{Tg} \mathrm{a}^{-1}$ from open burning, 400 to $520 \mathrm{Tg} \mathrm{a}^{-1}$ from biofuel use, and 780 to $1130 \mathrm{Tg} \mathrm{a}^{-1}$ for all biomass burning. Using the EFs from Table 1 and the activity estimates from
Table 2, we obtain a range of 390 to $1210 \mathrm{Tg} \mathrm{a}^{-1}$ for the $\mathrm{CO}$ emissions from open burning, in reasonable agreement with the inverse results. The range of biofuel $\mathrm{CO}$ emissions estimated from Tables 1 and 2 is only $181-196 \mathrm{Tg} \mathrm{a}^{-1}$, accounting for less than one-half of the inverse estimate. This suggests either that the amount of biofuel use is significantly underestimated in present bottom-up budgets or that the inversions attribute some of the open burning inaccurately to biofuel use. This could likely be the case for agricultural burning, which uses similar fuels and takes place in similar regions as biofuel use. The inverse analyses may also be useful to indicate unlikely estimates based on remotesensing techniques. For example, the burning of $8750 \mathrm{Tg}$ dry matter in tropical forests estimated by FLAMBE, combined with the corresponding $\mathrm{EF}_{\mathrm{CO}}\left(105 \mathrm{~g} \mathrm{~kg}^{-1}\right)$, would produce $\mathrm{CO}$ emissions of $900 \mathrm{Tg} \mathrm{a}^{-1}$ from this biome alone, well above the range of inverse $\mathrm{CO}$ emission estimates for all open burning (see also the comments by Reviewer 1; https://doi.org/10.5194/acp-2019-303-RC1).

Major differences between the present emission estimates and A\&M2001 are seen for the oxygenated volatile organic compounds and for HCN (as already noted in Akagi et al., 2011), which all are significantly greater in the present assessment than in A\&M2001. This is due to the large number of new and more accurate emission factor measurements 
Table 3. Global emission of selected species based on the emission factors in Table 1 and the biomass burning estimates in Table 2 (Tg $\mathrm{a}^{-1}$ ).

\begin{tabular}{|c|c|c|c|c|c|c|c|c|c|c|c|}
\hline & $\begin{array}{r}\text { Savanna and } \\
\text { grassland }\end{array}$ & $\begin{array}{r}\text { Tropical } \\
\text { forest }\end{array}$ & $\begin{array}{r}\text { Temperate } \\
\text { forest }\end{array}$ & $\begin{array}{r}\text { Boreal } \\
\text { forest }\end{array}$ & $\begin{array}{l}\text { Peat } \\
\text { fires }\end{array}$ & $\begin{array}{r}\text { Agricultural } \\
\text { residues }\end{array}$ & $\begin{array}{l}\text { Biofuel } \\
\text { burning }\end{array}$ & $\begin{array}{r}\text { Charcoal } \\
\text { making }\end{array}$ & $\begin{array}{r}\text { Charcoal } \\
\text { burning }\end{array}$ & Total & A\&M2001 \\
\hline $\mathrm{Tg}$ dry matter burned & 2400 & 2880 & 300 & 450 & 172 & 240 & 2134 & 180 & 45 & 8800 & 8600 \\
\hline $\mathrm{CO}_{2}$ & 3980 & 4670 & 470 & 690 & 270 & 340 & 3310 & 90 & 110 & 13900 & 13400 \\
\hline $\mathrm{CO}$ & 170 & 300 & 34 & 55 & 45 & 18 & 180 & 17 & 9.4 & 820 & 690 \\
\hline $\mathrm{CH}_{4}$ & 6.5 & 19 & 1.6 & 2.5 & 1.6 & 1.4 & 15 & 3.4 & 0.27 & 50 & 39 \\
\hline Total VOCs & 12.2 & 16 & 4.0 & 2.7 & 3.7 & 1.8 & 17 & 4.8 & 0.3 & 62 & 49 \\
\hline Total NMOGs* & 72 & 149 & 11.7 & 26 & 23 & 12.3 & 123 & 58 & 0.5 & 480 & 49 \\
\hline $\mathrm{C}_{2} \mathrm{H}_{2}$ & 0.75 & 1.0 & 0.09 & 0.13 & 0.02 & 0.07 & 1.4 & 0.05 & 0.012 & 3.6 & 3.7 \\
\hline Methanol & 3.2 & 8.1 & 0.7 & 1.0 & 0.4 & 0.8 & 4.3 & 2.3 & 0.04 & 21 & 12.7 \\
\hline Formaldehyde & 2.9 & 6.9 & 0.6 & 0.8 & 0.2 & 0.4 & 1.9 & - & 0.02 & 14 & 5.5 \\
\hline Acetaldehyde & 2.0 & 6.5 & 0.36 & 0.37 & 0.20 & 0.43 & 0.87 & - & 0.01 & 10.8 & 3.5 \\
\hline Acetone & 1.1 & 1.81 & 0.23 & 0.72 & 0.16 & 0.17 & 0.74 & 0.05 & 0.07 & 5.1 & 3.0 \\
\hline Acetonitrile & 0.40 & 1.42 & 0.07 & 0.14 & 0.10 & 0.06 & 0.21 & - & - & 2.4 & 1.3 \\
\hline Formic acid & 0.5 & 1.4 & 0.3 & 0.5 & 0.1 & 0.1 & 0.49 & 0.03 & 0.00 & 3.3 & 5.9 \\
\hline Acetic acid & 5.5 & 9.5 & 0.8 & 1.7 & 0.8 & 1.5 & 8.4 & 8.4 & 0.08 & 37 & 12.6 \\
\hline $\mathrm{H}_{2}$ & 2.3 & 8.9 & 0.6 & 0.7 & 0.2 & 0.6 & 3.9 & - & 0.21 & 18 & 15.3 \\
\hline $\mathrm{NO}_{x}$ & 6.0 & 8.1 & 0.9 & 0.5 & 0.2 & 0.6 & 2.7 & 0.04 & 0.11 & 19 & 21 \\
\hline $\mathrm{N}_{2} \mathrm{O}$ & 0.41 & 0.58 & 0.08 & 0.11 & - & 0.02 & 0.15 & 0.00 & 0.016 & 1.36 & 1.31 \\
\hline $\mathrm{NH}_{3}$ & 2.1 & 3.8 & 0.29 & 1.11 & 0.71 & 0.2 & 0.9 & 0.68 & 0.03 & 10.0 & 10.3 \\
\hline $\mathrm{HCN}$ & 1.06 & 1.26 & 0.19 & 0.24 & 0.76 & 0.10 & 0.83 & 0.02 & - & 4.5 & 0.9 \\
\hline $\mathrm{N}_{2}$ & 6.3 & 7.6 & 0.8 & 1.2 & - & 0.6 & 5.6 & - & - & 22 & 26 \\
\hline $\mathrm{SO}_{2}$ & 1.1 & 2.21 & 0.21 & 0.34 & 0.73 & 0.19 & 1.20 & - & 0.026 & 6.0 & 3.5 \\
\hline COS & 0.06 & 0.14 & 0.01 & 0.03 & 0.02 & 0.01 & 0.04 & - & - & 0.31 & 0.27 \\
\hline $\mathrm{CH}_{3} \mathrm{Cl}$ & 0.15 & 0.08 & 0.01 & 0.03 & 0.03 & 0.04 & 0.39 & - & 0.0005 & 0.73 & 0.65 \\
\hline $\mathrm{CH}_{3} \mathrm{Br}$ & 0.007 & 0.022 & 0.000 & 0.001 & 0.002 & 0.0003 & 0.001 & - & - & 0.034 & 0.029 \\
\hline $\mathrm{CH}_{3} \mathrm{I}$ & 0.0017 & 0.0196 & 0.0001 & 0.0002 & 0.0021 & 0.00004 & 0.0002 & - & - & 0.024 & 0.014 \\
\hline $\mathrm{Hg}$ & 0.0001 & 0.0003 & 0.00006 & 0.00010 & - & 0.00001 & 0.0001 & - & - & 0.0007 & 0.0008 \\
\hline $\mathrm{PM}_{2.5}$ & 16 & 24 & 5.5 & 8.4 & 3.2 & 2.0 & 14.5 & 3.6 & 0.14 & 77 & 58 \\
\hline TPM & 21 & 31 & 5.5 & 6.9 & 0.0 & 3.1 & 14.9 & 2.5 & 0.09 & 85 & 82 \\
\hline $\mathrm{TC}$ & 7.6 & 16 & 2.5 & 4.4 & 2.5 & 1.3 & 7.3 & - & 0.09 & 41 & 42 \\
\hline OC & 7.3 & 12.8 & 3.3 & 2.7 & 2.4 & 1.2 & 6.6 & - & 0.10 & 36 & 36 \\
\hline $\mathrm{BC}$ & 1.3 & 1.46 & 0.17 & 0.19 & 0.02 & 0.10 & 1.7 & - & 0.01 & 4.9 & 4.8 \\
\hline $\mathrm{K}$ & 0.95 & 0.93 & 0.05 & 0.08 & 0.001 & 0.12 & 0.28 & - & 0.03 & 2.4 & 1.9 \\
\hline $\mathrm{CN}$ & $5.5 \mathrm{E}+28$ & $1.1 \mathrm{E}+28$ & $2.8 \mathrm{E}+27$ & $1.9 \mathrm{E}+27$ & - & $1.2 \mathrm{E}+27$ & $6.3 \mathrm{E}+27$ & - & $2.2 \mathrm{E}+26$ & $7.9 \mathrm{E}+28$ & $2.9 \mathrm{E}+28$ \\
\hline CCN $(1 \% \mathrm{SS})$ & $1.9 \mathrm{E}+27$ & $4.8 \mathrm{E}+27$ & $6.0 \mathrm{E}+26$ & $7.3 \mathrm{E}+26$ & - & $2.5 \mathrm{E}+26$ & $2.4 \mathrm{E}+27$ & - & - & $1.1 \mathrm{E}+28$ & $1.7 \mathrm{E}+28$ \\
\hline$N(>\sim 0.12 \mu \mathrm{m})$ & $3.0 \mathrm{E}+27$ & $7.9 \mathrm{E}+27$ & $3.0 \mathrm{E}+26$ & $4.5 \mathrm{E}+26$ & - & $2.4 \mathrm{E}+26$ & $2.1 \mathrm{E}+27$ & - & - & $1.4 \mathrm{E}+28$ & $9.0 \mathrm{E}+27$ \\
\hline
\end{tabular}

* Using EFs from online updates to Akagi et al. (2011).

for these compounds, which have been made possible by improvements in analytical techniques since the 1990s.

\section{Conclusions}

We are left with the somewhat frustrating conclusion that, in spite of the great progress in emission factor measurements and detection and quantification of fires, the overall uncertainty of global biomass burning emissions has not decreased significantly for most substances since our previous analysis almost 20 years ago. Evidently, there is a great need for improved accuracy in the activity estimates, both for open burning and especially for biofuel use. For open burning, coordinated regional $\mathrm{CO}$ studies in regions and at times of high biomass burning activity, including both FRP- and burnedarea-based remote-sensing approaches as well as inversions, may be a way to resolve discrepancies and improve accuracy. This would be of great benefit for testing and improving fire emission models, which also give quite divergent results and have difficulties in capturing interannual variations and tem- poral trends. For example, the modeled estimates of carbon emitted from open burning in the nine models participating in the FireMIP project span from 1.0 to $4.9 \mathrm{Pg} \mathrm{a}^{-1}$ (F. Li et al., 2019).

With regard to emission factors, Table 1 can serve as a guide to prioritizing future research activities. Photochemically active species and toxic compounds for which there are only a few measurements from important fire types deserve more intense study. An example is the emission of PAHs, for which we have only one study from boreal fires and none at all from tropical forest fires. Given the toxicity of these compounds and the increasing exposure of populations in these regions to biomass smoke as a result of climate change and population growth, this seems an important knowledge gap. Another example are the emissions of semivolatile and intermediate-volatile compounds (I/SVOCs), which are important in the context of organic aerosol production from biomass burning but for which at this time only laboratory measurements are available (Hatch et al., 2018). I have already referred to the lack of field measurements of alkyl 
amine emissions, which may be of importance for new particle formation. In view of the grave health risk associated with aerosol particles (see, e.g., Lelieveld et al., 2019, and references therein) and the growing exposure to wildfire smoke in areas like the western USA, the accuracy and fire condition dependence of PM emissions need to be improved. Emphasis should be on field measurements under a variety of representative conditions, to represent the influence of parameters like fuel moisture and fire weather. While the approach in this paper is focused on global averages, future work should also emphasize regional and seasonal differences in order to better support more highly geographically resolved modeling. A spreadsheet containing Table 1, the underlying data, and the corresponding references is available at https://doi.org/10.17617/3.26 (Andreae, 2019), where periodical updates will also be provided.

Data availability. A spreadsheet containing Table 1, the data on which the averages in Table 1 are based, and the corresponding references is available at https://doi.org/10.17617/3.26 (Andreae, 2019).

Supplement. The supplement related to this article is available online at: https://doi.org/10.5194/acp-19-8523-2019-supplement.

Competing interests. The author declares that there is no conflict of interest.

Acknowledgements. I thank Johannes Kaiser, Imke Hüser, Zbigniew Klimont, Anton Darmenov, Edward Hyer, and Steven Smith for providing estimates of biomass burned from their respective databases, Maximilien Desserrvetaz for unpublished emission data, and Robert Yokelson, Charles Ichoku, Nic Surawski, James Roberts, and an anonymous reviewer for comments on the manuscript. This work was supported by the German Max Planck Society.

Financial support. The article processing charges for this openaccess publication were covered by the Max Planck Society.

Review statement. This paper was edited by Qiang Zhang and reviewed by Charles Ichoku, Robert Yokelson, and one anonymous referee.

\section{References}

Adams, C., McLinden, C. A., Shephard, M. W., Dickson, N., Dammers, E., Chen, J., Makar, P., Cady-Pereira, K. E., Tam, N., Kharol, S. K., Lamsal, L. N., and Krotkov, N. A.: Satellitederived emissions of carbon monoxide, ammonia, and nitrogen dioxide from the 2016 Horse River wildfire in the Fort McMurray area, Atmos. Chem. Phys., 19, 2577-2599, https://doi.org/10.5194/acp-19-2577-2019, 2019.

Ahern, A. T., Robinson, E. S., Tkacik, D. S., Saleh, R., Hatch, L. E., Barsanti, K. C., Stockwell, C. E., Yokelson, R. J., Presto, A. A., Robinson, A. L., Sullivan, R. C., and Donahue, N. M.: Production of secondary organic aerosol during aging of biomass burning smoke from fresh fuels and its relationship to VOC precursors, J. Geophys. Res., 124, 3583-3606, https://doi.org/10.1029/2018JD029068, 2019.

Aiken, A. C., Decarlo, P. F., Kroll, J. H., Worsnop, D. R., Huffman, J. A., Docherty, K. S., Ulbrich, I. M., Mohr, C., Kimmel, J. R., Sueper, D., Sun, Y., Zhang, Q., Trimborn, A. Northway, M., Ziemann, P. J., Canagaratna, M. R., Onasch, T. B., Alfarra, M. R., Prevot, A. S. H., Dommen, J., Duplissy, J., Metzger, A., Baltensperger, U., and Jimenez, J. L.: $\mathrm{O} / \mathrm{C}$ and $\mathrm{OM} / \mathrm{OC}$ ratios of primary, secondary, and ambient organic aerosols with high-resolution time-of-flight aerosol mass spectrometry, Environ. Sci. Technol., 42, 4478-4485, https://doi.org/10.1021/es703009q, 2008.

Akagi, S. K., Yokelson, R. J., Wiedinmyer, C., Alvarado, M. J., Reid, J. S., Karl, T., Crounse, J. D., and Wennberg, P. O.: Emission factors for open and domestic biomass burning for use in atmospheric models, Atmos. Chem. Phys., 11, 4039-4072, https://doi.org/10.5194/acp-11-4039-2011, 2011.

Akagi, S. K., Yokelson, R. J., Burling, I. R., Meinardi, S., Simpson, I., Blake, D. R., McMeeking, G. R., Sullivan, A., Lee, T., Kreidenweis, S., Urbanski, S., Reardon, J., Griffith, D. W. T., Johnson, T. J., and Weise, D. R.: Measurements of reactive trace gases and variable $\mathrm{O}_{3}$ formation rates in some South Carolina biomass burning plumes, Atmos. Chem. Phys., 13, 1141-1165, https://doi.org/10.5194/acp-13-1141-2013, 2013.

Akagi, S. K., Burling, I. R., Mendoza, A., Johnson, T. J., Cameron, M., Griffith, D. W. T., Paton-Walsh, C., Weise, D. R., Reardon, J., and Yokelson, R. J.: Field measurements of trace gases emitted by prescribed fires in southeastern US pine forests using an open-path FTIR system, Atmos. Chem. Phys., 14, 199-215, https://doi.org/10.5194/acp-14-199-2014, 2014.

Almeida, J., Schobesberger, S., Kurten, A., Ortega, I. K., Kupiainen-Maatta, O., Praplan, A. P., Adamov, A., Amorim, A., Bianchi, F., Breitenlechner, M., David, A., Dommen, J., Donahue, N. M., Downard, A., Dunne, E., Duplissy, J., Ehrhart, S., Flagan, R. C., Franchin, A., Guida, R., Hakala, J., Hansel, A., Heinritzi, M., Henschel, H., Jokinen, T., Junninen, H., Kajos, M., Kangasluoma, J., Keskinen, H., Kupc, A., Kurten, T., Kvashin, A. N., Laaksonen, A., Lehtipalo, K., Leiminger, M., Leppa, J., Loukonen, V., Makhmutov, V., Mathot, S., McGrath, M. J., Nieminen, T., Olenius, T., Onnela, A., Petaja, T., Riccobono, F., Riipinen, I., Rissanen, M., Rondo, L., Ruuskanen, T., Santos, F. D., Sarnela, N., Schallhart, S., Schnitzhofer, R., Seinfeld, J. H., Simon, M., Sipila, M., Stozhkov, Y., Stratmann, F., Tome, A., Trostl, J., Tsagkogeorgas, G., Vaattovaara, P., Viisanen, Y., Virtanen, A., Vrtala, A., Wagner, P. E., Weingartner, E., Wex, H., Williamson, C., Wimmer, D., Ye, P., Yli-Juuti, T., Carslaw, K. 
S., Kulmala, M., Curtius, J., Baltensperger, U., Worsnop, D. R., Vehkamaki, H., and Kirkby, J.: Molecular understanding of sulphuric acid-amine particle nucleation in the atmosphere, Nature, 502, 359-363, https://doi.org/10.1038/nature12663, 2013.

Andreae, M. O.: Biomass burning: Its history, use and distribution and its impact on environmental quality and global climate, in: Global Biomass Burning: Atmospheric, Climatic and Biospheric Implications, edited by: Levine, J. S., 3-21, MIT Press, Cambridge, Mass., USA, 1991.

Andreae, M. O.: Biomass Burning Emission Factors, https://doi.org/10.17617/3.26, 2019.

Andreae, M. O. and Gelencsér, A.: Black carbon or brown carbon? The nature of light-absorbing carbonaceous aerosols, Atmos. Chem. Phys., 6, 3131-3148, https://doi.org/10.5194/acp-63131-2006, 2006.

Andreae, M. O. and Merlet, P.: Emission of trace gases and aerosols from biomass burning, Global Biogeochem. Cy., 15, 955-966, 2001.

Andreae, M. O. and Rosenfeld, D.: Aerosol-cloud-precipitation interactions. Part 1. The nature and sources of cloud-active aerosols, Earth-Sci. Rev., 89, 13-41, 2008.

Andreae, M. O., Andreae, T. W., Annegarn, H., Beer, F., Cachier, H., Elbert, W., Harris, G. W., Maenhaut, W., Salma, I., Swap, R., Wienhold, F. G., and Zenker, T.: Airborne studies of aerosol emissions from savanna fires in southern Africa: 2. Aerosol chemical composition, J. Geophys. Res., 103, 32119-32128, 1998.

Andreae, M. O., Rosenfeld, D., Artaxo, P., Costa, A. A., Frank, G. P., Longo, K. M., and Silva-Dias, M. A. F.: Smoking rain clouds over the Amazon, Science, 303, 1337-1342, 2004.

Andreae, M. O., Hegg, D., and Baltensperger, U.: Sources and nature of atmospheric aerosols, in: Aerosol Pollution Impact on Precipitation: A Scientific Review, edited by: Levin, Z. and Cotton, W., 45-89, Springer, Heidelberg, Germany, 2009.

Andreae, M. O., Artaxo, P., Beck, V., Bela, M., Freitas, S., Gerbig, C., Longo, K., Munger, J. W., Wiedemann, K. T., and Wofsy, S. C.: Carbon monoxide and related trace gases and aerosols over the Amazon Basin during the wet and dry seasons, Atmos. Chem. Phys., 12, 6041-6065, https://doi.org/10.5194/acp12-6041-2012, 2012.

Apte, J. S., Brauer, M., Cohen, A. J., Ezzati, M., and Pope, C. A.: Ambient $\mathrm{PM}_{2.5}$ reduces global and regional life expectancy, Environ. Sci. Technol. Lett., 5, 546-551, https://doi.org/10.1021/acs.estlett.8b00360, 2018.

Artaxo, P., Rizzo, L. V., Paixao, M., de Lucca, S., Oliveira, P. H., Lara, L. L., Wiedemann, K. T., Andreae, M. O., Holben, B., Schafer, J., Correia, A. L., and Pauliquevis, T. M.: Aerosol Particles in Amazonia: Their Composition, Role in the Radiation Balance, Cloud Formation, and Nutrient Cycles, in: Amazonia and Global Change, edited by: Keller, M., Bustamante, M., Gash, J., and Dias, P. S., 233-250, https://doi.org/10.1029/2008gm000778, 2009.

Bertschi, I., Yokelson, R. J., Ward, D. E., Babbitt, R. E., Susott, R. A., Goode, J. G., and Hao, W. M.: Trace gas and particle emissions from fires in large diameter and belowground biomass fuels, J. Geophys. Res., 108, 8472, https://doi.org/10.1029/2002JD002100, 2003.

Bond, T. C., Doherty, S. J., Fahey, D. W., Forster, P. M., Berntsen, T., DeAngelo, B. J., Flanner, M. G., Ghan, S., Kärcher, B.,
Koch, D., Kinne, S., Kondo, Y., Quinn, P. K., Sarofim, M. C., Schultz, M. G., Schulz, M., Venkataraman, C., Zhang, H., Zhang, S., Bellouin, N., Guttikunda, S. K., Hopke, P. K., Jacobson, M. Z., Kaiser, J. W., Klimont, Z., Lohmann, U., Schwarz, J. P., Shindell, D., Storelvmo, T., Warren, S. G., and Zender, C. S.: Bounding the role of black carbon in the climate system: A scientific assessment, J. Geophys. Res., 118, 1-173, https://doi.org/10.1002/jgrd.50171, 2013.

Braga, R. C., Rosenfeld, D., Weigel, R., Jurkat, T., Andreae, M. O., Wendisch, M., Pöschl, U., Voigt, C., Mahnke, C., Borrmann, S., Albrecht, R. I., Molleker, S., Vila, D. A., Machado, L. A. T., and Grulich, L.: Further evidence for CCN aerosol concentrations determining the height of warm rain and ice initiation in convective clouds over the Amazon basin, Atmos. Chem. Phys., 17, 1443314456, https://doi.org/10.5194/acp-17-14433-2017, 2017.

Brito, J., Rizzo, L. V., Morgan, W. T., Coe, H., Johnson, B., Haywood, J., Longo, K., Freitas, S., Andreae, M. O., and Artaxo, P.: Ground-based aerosol characterization during the South American Biomass Burning Analysis (SAMBBA) field experiment, Atmos. Chem. Phys., 14, 12069-12083, https://doi.org/10.5194/acp-14-12069-2014, 2014.

Burling, I. R., Yokelson, R. J., Akagi, S. K., Urbanski, S. P., Wold, C. E., Griffith, D. W. T., Johnson, T. J., Reardon, J., and Weise, D. R.: Airborne and ground-based measurements of the trace gases and particles emitted by prescribed fires in the United States, Atmos. Chem. Phys., 11, 12197-12216, https://doi.org/10.5194/acp-11-12197-2011, 2011.

Burnett, R., Chen, H., Szyszkowicz, M., Fann, N., Hubbell, B., Pope, C. A., Apte, J. S., Brauer, M., Cohen, A., Weichenthal, S., Coggins, J., Di, Q., Brunekreef, B., Frostad, J., Lim, S. S., Kan, H., Walker, K. D., Thurston, G. D., Hayes, R. B., Lim, C. C., Turner, M. C., Jerrett, M., Krewski, D., Gapstur, S. M., Diver, W. R., Ostro, B., Goldberg, D., Crouse, D. L., Martin, R. V., Peters, P., Pinault, L., Tjepkema, M., van Donkelaar, A., Villeneuve, P. J., Miller, A. B., Yin, P., Zhou, M., Wang, L., Janssen, N. A. H., Marra, M., Atkinson, R. W., Tsang, H., Quoc Thach, T., Cannon, J. B., Allen, R. T., Hart, J. E., Laden, F., Cesaroni, G., Forastiere, F., Weinmayr, G., Jaensch, A., Nagel, G., Concin, H., and Spadaro, J. V.: Global estimates of mortality associated with long-term exposure to outdoor fine particulate matter, P. Natl. Acad. Sci. USA, 115, 9592-9597, https://doi.org/10.1073/pnas.1803222115, 2018.

Cecchini, M. A., Machado, L. A. T., Andreae, M. O., Martin, S. T., Albrecht, R. I., Artaxo, P., Barbosa, H. M. J., Borrmann, S., Fütterer, D., Jurkat, T., Mahnke, C., Minikin, A., Molleker, S., Pöhlker, M. L., Pöschl, U., Rosenfeld, D., Voigt, C., Weinzierl, B., and Wendisch, M.: Sensitivities of Amazonian clouds to aerosols and updraft speed, Atmos. Chem. Phys., 17, 1003710050, https://doi.org/10.5194/acp-17-10037-2017, 2017.

Chatfield, R. B., Andreae, M. O., and ARCTAS and SEAC4RS Science Teams: Emissions Relationships in Western Forest Fire Plumes: I. Reducing the Effect of Mixing Errors on Emission Factors, Atmos. Meas. Tech., submitted, 2019.

Chen, L.-W. A., Verburg, P., Shackelford, A., Zhu, D., Susfalk, R., Chow, J. C., and Watson, J. G.: Moisture effects on carbon and nitrogen emission from burning of wildland biomass, Atmos. Chem. Phys., 10, 6617-6625, https://doi.org/10.5194/acp10-6617-2010, 2010. 
Chen, Y., Randerson, J. T., van der Werf, G. R., Morton, D. C., Mu, M. Q., and Kasibhatla, P. S.: Nitrogen deposition in tropical forests from savanna and deforestation fires, Glob. Change Biol., 16, 2024-2038, https://doi.org/10.1111/j.13652486.2009.02156.x, 2010.

Christian, T. J., Kleiss, B., Yokelson, R. J., Holzinger, R., Crutzen, P. J., Hao, W. M., Saharjo, B. H., and Ward, D. E.: Comprehensive laboratory measurements of biomass-burning emissions: 1. Emissions from Indonesian, African, and other fuels, J. Geophys. Res., 108, 4719, https://doi.org/10.1029/2003JD003704, 2003.

Chuvieco, E., Yue, C., Heil, A., Mouillot, F., Alonso-Canas, I., Padilla, M., Pereira, J. M., Oom, D., and Tansey, K.: A new global burned area product for climate assessment of fire impacts, Global Ecol. Biogeogr., 25, 619-629, https://doi.org/10.1111/geb.12440, 2016.

Ciais, P., Sabine, C., Bala, G., Bopp, L., Brovkin, V., Canadell, J., Chhabra, A., DeFries, R., Galloway, J., Heimann, M., Jones, C., Quéré, C. L., Myneni, R. B., Piao, S., and Thornton, P.: Carbon and Other Biogeochemical Cycles, chap. 6 , in: IPCC, Climate Change 2013: The Physical Science Basis. Contribution of Working Group I to the Fifth Assessment Report of the Intergovernmental Panel on Climate Change, edited by: Stocker, T. F., Qin, D., Plattner, G.-K., Tignor, M., Allen, S. K., Boschung, J., Nauels, A., Xia, Y., Bex, V., and Midgley, P. M., 465-570, Cambridge University Press, Cambridge, UK and New York, NY, USA, 2013.

Coffey, E. R., Muvandimwe, D., Hagar, Y., Wiedinmyer, C., Kanyomse, E., Piedrahita, R., Dickinson, K. L., Oduro, A., and Hannigan, M. P.: New emission factors and efficiencies from infield measurements of traditional and improved cookstoves and their potential implications, Environ. Sci. Technol., 51, 12,50812,517, https://doi.org/10.1021/acs.est.7b02436, 2017.

Cohen, A. J., Brauer, M., Burnett, R., Anderson, H. R., Frostad, J., Estep, K., Balakrishnan, K., Brunekreef, B., Dandona, L., Dandona, R., Feigin, V., Freedman, G., Hubbell, B., Jobling, A., Kan, H., Knibbs, L., Liu, Y., Martin, R., Morawska, L., Pope, C. A., Shin, H., Straif, K., Shaddick, G., Thomas, M., van Dingenen, R., van Donkelaar, A., Vos, T., Murray, C. J. L., and Forouzanfar, M. H.: Estimates and 25-year trends of the global burden of disease attributable to ambient air pollution: an analysis of data from the Global Burden of Diseases Study 2015, Lancet, 389, 1907-1918, https://doi.org/10.1016/S0140-6736(17)30505-6, 2017.

Collard, F.-X. and Blin, J.: A review on pyrolysis of biomass constituents: Mechanisms and composition of the products obtained from the conversion of cellulose, hemicelluloses and lignin, Renew. Sust. Energ. Rev., 38, 594-608, https://doi.org/10.1016/j.rser.2014.06.013, 2014.

Collier, S., Zhou, S., Onasch, T. B., Jaffe, D. A., Kleinman, L., Sedlacek, A. J., Briggs, N. L., Hee, J., Fortner, E., Shilling, J. E., Worsnop, D., Yokelson, R. J., Parworth, C., Ge, X. L., Xu, J. Z., Butterfield, Z., Chand, D., Dubey, M. K., Pekour, M. S., Springston, S., and Zhang, Q.: Regional influence of aerosol emissions from wildfires driven by combustion efficiency: Insights from the BBOP campaign, Environ. Sci. Technol., 50, 8613-8622, https://doi.org/10.1021/acs.est.6b01617, 2016.

Crutzen, P. J. and Andreae, M. O.: Biomass burning in the tropics: Impact on atmospheric chemistry and biogeochemical cycles, Science, 250, 1669-1678, 1990.
Darmenov, A. S. and da Silva, A.: The Quick Fire Emissions Dataset (QFED): Documentation of versions 2.1, 2.2 and 2.4, in: Technical Report Series on Global Modeling and Data Assimilation, edited by: Koster, R. D., 212 pp., NASA Goddard Space Flight Center, Greenbelt, MD, USA, 2015.

Deeter, M. N., Martínez-Alonso, S., Gatti, L. V., Gloor, M., Miller, J. B., Domingues, L. G., and Correia, C. S. C.: Validation and analysis of MOPITT CO observations of the Amazon Basin, Atmos. Meas. Tech., 9, 3999-4012, https://doi.org/10.5194/amt-93999-2016, 2016.

Dennekamp, M., Straney, L. D., Erbas, B., Abramson, M. J., Keywood, M., Smith, K., Sim, M. R., Glass, D. C., Del Monaco, A., Haikerwal, A., and Tonkin, A. M.: Forest fire smoke exposures and out-of-hospital cardiac arrests in Melbourne, Australia: A case-crossover study, Environ. Health Persp., 123, 959-964, https://doi.org/10.1289/ehp.1408436, 2015.

Fang, Z., Deng, W., Zhang, Y., Ding, X., Tang, M., Liu, T., Hu, Q., Zhu, M., Wang, Z., Yang, W., Huang, Z., Song, W., Bi, X., Chen, J., Sun, Y., George, C., and Wang, X.: Open burning of rice, corn and wheat straws: primary emissions, photochemical aging, and secondary organic aerosol formation, Atmos. Chem. Phys., 17, 14821-14839, https://doi.org/10.5194/acp-17-148212017, 2017.

FAO Forestry Policy and Resources Division: 2014 Global Forest Products Facts and Figures, Rome, Italy, 16 p., 2015.

Fernandes, S. D., Trautmann, N. M., Streets, D. G., Roden, C. A., and Bond, T. C.: Global biofuel use, 1850-2000, Global Biogeochem. Cy., 21, GB2019, https://doi.org/10.1029/2006GB002836, 2007.

Fleming, L. T., Lin, P., Roberts, J. M., Selimovic, V., Yokelson, R., Laskin, J., Laskin, A., and Nizkorodov, S. A.: Molecular composition and photochemical lifetimes of brown carbon chromophores in biomass burning organic aerosol, Atmos. Chem. Phys. Discuss., https://doi.org/10.5194/acp-2019-523, in review, 2019.

Forrister, H., Liu, J., Scheuer, E., Dibb, J., Ziemba, L., Thornhill, K. L., Anderson, B., Diskin, G., Perring, A. E., Schwarz, J. P., Campuzano-Jost, P., Day, D. A., Palm, B. B., Jimenez, J. L., Nenes, A., and Weber, R. J.: Evolution of brown carbon in wildfire plumes, Geophys. Res. Lett., 42, 4623-4630, https://doi.org/10.1002/2015gl063897, 2015.

Fortner, E., Onasch, T., Canagaratna, M., Williams, L. R., Lee, T., Jayne, J., and Worsnop, D.: Examining the chemical composition of black carbon particles from biomass burning with SP-AMS, J. Aerosol Sci., 120, 12-21, https://doi.org/10.1016/j.jaerosci.2018.03.001, 2018.

Friedli, H. R., Arellano, A. F., Cinnirella, S., and Pirrone, N.: Mercury Emissions from Global Biomass Burning: Spatial and Temporal Distribution, in: Mercury Fate and Transport in the Global Atmosphere: Emissions, Measurements and Models, edited by: Pirrone, N. and Mason, R., 193-220, https://doi.org/10.1007/978-0-387-93958-2_8, 2009.

Gatti, L. V., Gloor, M., Miller, J. B., Doughty, C. E., Malhi, Y., Domingues, L. G., Basso, L. S., Martinewski, A., Correia, C. S. C., Borges, V. F., Freitas, S., Braz, R., Anderson, L. O., Rocha, H., Grace, J., Phillips, O. L., and Lloyd, J.: Drought sensitivity of Amazonian carbon balance revealed by atmospheric measurements, Nature, 506, 76-80, https://doi.org/10.1038/nature12957, 2014. 
Geron, C. and Hays, M.: Air emissions from organic soil burning on the coastal plain of North Carolina, Atmos. Environ., 64, 192199, https://doi.org/10.1016/j.atmosenv.2012.09.065, 2013.

Goetz, J. D., Giordano, M. R., Stockwell, C. E., Christian, T. J., Maharjan, R., Adhikari, S., Bhave, P. V., Praveen, P. S., Panday, A. K., Jayarathne, T., Stone, E. A., Yokelson, R. J., and DeCarlo, P. F.: Speciated online PM1 from South Asian combustion sources - Part 1: Fuel-based emission factors and size distributions, Atmos. Chem. Phys., 18, 14653-14679, https://doi.org/10.5194/acp-18-14653-2018, 2018.

Guyon, P., Frank, G. P., Welling, M., Chand, D., Artaxo, P., Rizzo, L., Nishioka, G., Kolle, O., Fritsch, H., Silva Dias, M. A. F., Gatti, L. V., Cordova, A. M., and Andreae, M. O.: Airborne measurements of trace gas and aerosol particle emissions from biomass burning in Amazonia, Atmos. Chem. Phys., 5, 29893002, https://doi.org/10.5194/acp-5-2989-2005, 2005.

Hamilton, D. S., Hantson, S., Scott, C. E., Kaplan, J. O., Pringle, K. J., Nieradzik, L. P., Rap, A., Folberth, G. A., Spracklen, D. V., and Carslaw, K. S.: Reassessment of pre-industrial fire emissions strongly affects anthropogenic aerosol forcing, Nat. Commun., 9, 3182, https://doi.org/10.1038/s41467-018-05592-9, 2018.

Hao, W. M. and Babbitt, R. E.: Smoke production from residual combustion. Final Report 98-1-9-01, Joint Fire Science Program ,Fire Sciences Laboratory, Missoula, Montana, USA, 25 pp., 2007.

Hatch, L. E., Yokelson, R. J., Stockwell, C. E., Veres, P. R., Simpson, I. J., Blake, D. R., Orlando, J. J., and Barsanti, K. C.: Multi-instrument comparison and compilation of non-methane organic gas emissions from biomass burning and implications for smoke-derived secondary organic aerosol precursors, Atmos. Chem. Phys., 17, 1471-1489, https://doi.org/10.5194/acp17-1471-2017, 2017.

Hatch, L. E., Rivas-Ubach, A., Jen, C. N., Lipton, M., Goldstein, A. H., and Barsanti, K. C.: Measurements of I/SVOCs in biomass-burning smoke using solid-phase extraction disks and two-dimensional gas chromatography, Atmos. Chem. Phys., 18, 17801-17817, https://doi.org/10.5194/acp-18-17801-2018, 2018.

Hobbs, P. V., Sinha, P., Yokelson, R. J., Christian, T. J., Blake, D. R., Gao, S., Kirchstetter, T. W., Novakov, T., and Pilewskie, P.: Evolution of gases and particles from a savanna fire in South Africa, J. Geophys. Res., 108, 8485, https://doi.org/10.1029/2002JD002352, 2003.

Hodgson, A. K., Morgan, W. T., O’Shea, S., Bauguitte, S., Allan, J. D., Darbyshire, E., Flynn, M. J., Liu, D., Lee, J., Johnson, B., Haywood, J. M., Longo, K. M., Artaxo, P. E., and Coe, H.: Near-field emission profiling of tropical forest and Cerrado fires in Brazil during SAMBBA 2012, Atmos. Chem. Phys., 18, 56195638, https://doi.org/10.5194/acp-18-5619-2018, 2018.

Hodshire, A. L., Bian, Q., Ramnarine, E., Lonsdale, C. R., Alvarado, M. J., Kreidenweis, S. M., Jathar, S. H., and Pierce, J. R.: More than emissions and chemistry: Fire size, dilution, and background aerosol also greatly influence near-field biomass burning aerosol aging, J. Geophys. Res., 124, 55895611, https://doi.org/10.1029/2018JD029674, 2019.

Hoesly, R. M., Smith, S. J., Feng, L., Klimont, Z., JanssensMaenhout, G., Pitkanen, T., Seibert, J. J., Vu, L., Andres, R. J., Bolt, R. M., Bond, T. C., Dawidowski, L., Kholod, N., Kurokawa, J.-I., Li, M., Liu, L., Lu, Z., Moura, M. C. P.,
O'Rourke, P. R., and Zhang, Q.: Historical (1750-2014) anthropogenic emissions of reactive gases and aerosols from the Community Emissions Data System (CEDS), Geosci. Model Dev., 11, 369-408, https://doi.org/10.5194/gmd-11-369-2018, 2018.

Hoffa, E. A., Ward, D. E., Hao, W. M., Susott, R. A., and Wakimoto, R. H.: Seasonality of carbon emissions from biomass burning in a Zambian savanna, J. Geophys. Res., 104, 13841-13853, 1999.

Ichoku, C. and Ellison, L.: Global top-down smoke-aerosol emissions estimation using satellite fire radiative power measurements, Atmos. Chem. Phys., 14, 6643-6667, https://doi.org/10.5194/acp-14-6643-2014, 2014.

Ito, A. and Penner, J. E.: Global estimates of biomass burning emissions based on satellite imagery for the year 2000, J. Geophys. Res., 109, D14S05, https://doi.org/10.1029/2003JD004423, 2004.

Jaffe, D. A. and Wigder, N. L.: Ozone production from wildfires: A critical review, Atmos. Environ., 51, 1-10, https://doi.org/10.1016/j.atmosenv.2011.11.063, 2012.

Janhäll, S., Andreae, M. O., and Pöschl, U.: Biomass burning aerosol emissions from vegetation fires: particle number and mass emission factors and size distributions, Atmos. Chem. Phys., 10, 1427-1439, https://doi.org/10.5194/acp-101427-2010, 2010.

Jayarathne, T., Stockwell, C. E., Bhave, P. V., Praveen, P. S., Rathnayake, C. M., Islam, Md. R., Panday, A. K., Adhikari, S., Maharjan, R., Goetz, J. D., DeCarlo, P. F., Saikawa, E., Yokelson, R. J., and Stone, E. A.: Nepal Ambient Monitoring and Source Testing Experiment (NAMaSTE): emissions of particulate matter from wood- and dung-fueled cooking fires, garbage and crop residue burning, brick kilns, and other sources, Atmos. Chem. Phys., 18, 2259-2286, https://doi.org/10.5194/acp18-2259-2018, 2018a.

Jayarathne, T., Stockwell, C. E., Gilbert, A. A., Daugherty, K., Cochrane, M. A., Ryan, K. C., Putra, E. I., Saharjo, B. H., Nurhayati, A. D., Albar, I., Yokelson, R. J., and Stone, E. A.: Chemical characterization of fine particulate matter emitted by peat fires in Central Kalimantan, Indonesia, during the 2015 El Niño, Atmos. Chem. Phys., 18, 2585-2600, https://doi.org/10.5194/acp-18-2585-2018, 2018 b.

Jen, C. N., Hatch, L. E., Selimovic, V., Yokelson, R. J., Weber, R., Fernandez, A. E., Kreisberg, N. M., Barsanti, K. C., and Goldstein, A. H.: Speciated and total emission factors of particulate organics from burning western US wildland fuels and their dependence on combustion efficiency, Atmos. Chem. Phys., 19, 1013-1026, https://doi.org/10.5194/acp-19-1013-2019, 2019.

Jiang, Y., Lu, Z., Liu, X., Qian, Y., Zhang, K., Wang, Y., and Yang, X.-Q.: Impacts of global open-fire aerosols on direct radiative, cloud and surface-albedo effects simulated with CAM5, Atmos. Chem. Phys., 16, 14805-14824, https://doi.org/10.5194/acp-1614805-2016, 2016.

Johnston, F. H., Henderson, S. B., Chen, Y., Randerson, J. T., Marlier, M., DeFries, R. S., Kinney, P., Bowman, D. M. J. S., and Brauer, M.: Estimated global mortality attributable to smoke from landscape fires, Environ. Health Persp., 120, 695-701, https://doi.org/10.1289/ehp.1104422, 2012.

Kaiser, J. W., Heil, A., Andreae, M. O., Benedetti, A., Chubarova, N., Jones, L., Morcrette, J.-J., Razinger, M., Schultz, M. G., Suttie, M., and van der Werf, G. R.: Biomass burning emissions estimated with a global fire assimilation system based 
on observed fire radiative power, Biogeosciences, 9, 527-554, https://doi.org/10.5194/bg-9-527-2012, 2012.

Klimont, Z., Kupiainen, K., Heyes, C., Purohit, P., Cofala, J., Rafaj, P., Borken-Kleefeld, J., and Schöpp, W.: Global anthropogenic emissions of particulate matter including black carbon, Atmos. Chem. Phys., 17, 8681-8723, https://doi.org/10.5194/acp-178681-2017, 2017.

Knorr, W., Dentener, F., Lamarque, J.-F., Jiang, L., and Arneth, A.: Wildfire air pollution hazard during the 21 st century, Atmos. Chem. Phys., 17, 9223-9236, https://doi.org/10.5194/acp17-9223-2017, 2017.

Kodros, J. K., Carter, E., Brauer, M., Volckens, J., Bilsback, K. R., L'Orange, C., Johnson, M., and Pierce, J. R.: Quantifying the contribution to uncertainty in mortality attributed to household, ambient, and joint exposure to $\mathrm{PM}_{2.5}$ from residential solid fuel use, GeoHealth, 2, 25-39, https://doi.org/10.1002/2017GH000115, 2018

Konovalov, I. B., Beekmann, M., Golovushkin, N. A., and Andreae, M. O.: Nonlinear behavior of organic aerosol in biomass burning plumes: a microphysical model analysis, Atmos. Chem. Phys. Discuss., https://doi.org/10.5194/acp-2019-425, in review, 2019.

Korontzi, S.: Seasonal patterns in biomass burning emissions from southern African vegetation fires for the year 2000, Glob. Change Biol., 11, 1680-1700, https://doi.org/10.1111/j.13652486.2005.001024.x, 2005.

Korontzi, S., Ward, D. E., Susott, R. A., Yokelson, R. J., Justice, C. O., Hobbs, P. V., Smithwick, E. A. H., and Hao, W. M.: Seasonal variation and ecosystem dependence of emission factors for selected trace gases and $\mathrm{PM}_{2.5}$ for southern African savanna fires, J. Geophys. Res., 108, 4758, https://doi.org/10.1029/2003JD003730, 2003.

Korontzi, S., Roy, D. P., Justice, C. O., and Ward, D. E.: Modeling and sensitivity analysis of fire emissions in southern Africa during SAFARI 2000, Remote Sens. Environ., 92, 255-275, 2004.

Kostenidou, E., Kaltsonoudis, C., Tsiflikiotou, M., Louvaris, E., Russell, L. M., and Pandis, S. N.: Burning of olive tree branches: a major organic aerosol source in the Mediterranean, Atmos. Chem. Phys., 13, 8797-8811, https://doi.org/10.5194/acp-138797-2013, 2013.

Kürten, A., Jokinen, T., Simon, M., Sipilä, M., Sarnela, N., Junninen, H., Adamov, A., Almeida, J., Amorim, A., Bianchi, F., Breitenlechner, M., Dommen, J., Donahue, N. M., Duplissy, J., Ehrhart, S., Flagan, R. C., Franchin, A., Hakala, J., Hansel, A., Heinritzi, M., Hutterli, M., Kangasluoma, J., Kirkby, J., Laaksonen, A., Lehtipalo, K., Leiminger, M., Makhmutov, V., Mathot, S., Onnela, A., Petäjä, T., Praplan, A. P., Riccobono, F., Rissanen, M. P., Rondo, L., Schobesberger, S., Seinfeld, J. H., Steiner, G., Tomé, A., Tröstl, J., Winkler, P. M., Williamson, C., Wimmer, D., Ye, P., Baltensperger, U., Carslaw, K. S., Kulmala, M., Worsnop, D. R., and Curtius, J.: Neutral molecular cluster formation of sulfuric acid-dimethylamine observed in real time under atmospheric conditions, P. Natl. Acad. Sci. USA, 111, 1501915024, https://doi.org/10.1073/pnas.1404853111, 2014.

Lelieveld, J. and Pöschl, U.: Chemists can help to solve the airpollution health crisis, Nature, 551, 291-293, 2017.

Lelieveld, J., Klingmüller, K., Pozzer, A., Burnett, R. T., Haines, A., and Ramanathan, V.: Effects of fossil fuel and total anthropogenic emission removal on public health and climate, P. Natl. Acad. Sci. USA, 116, 7192-7197, https://doi.org/10.1073/pnas.1819989116, 2019.

Le Quéré, C., Andrew, R. M., Friedlingstein, P., Sitch, S., Hauck, J., Pongratz, J., Pickers, P. A., Korsbakken, J. I., Peters, G. P., Canadell, J. G., Arneth, A., Arora, V. K., Barbero, L., Bastos, A., Bopp, L., Chevallier, F., Chini, L. P., Ciais, P., Doney, S. C., Gkritzalis, T., Goll, D. S., Harris, I., Haverd, V., Hoffman, F. M., Hoppema, M., Houghton, R. A., Hurtt, G., Ilyina, T., Jain, A. K., Johannessen, T., Jones, C. D., Kato, E., Keeling, R. F., Goldewijk, K. K., Landschützer, P., Lefèvre, N., Lienert, S., Liu, Z., Lombardozzi, D., Metzl, N., Munro, D. R., Nabel, J. E. M. S., Nakaoka, S.-I., Neill, C., Olsen, A., Ono, T., Patra, P., Peregon, A., Peters, W., Peylin, P., Pfeil, B., Pierrot, D., Poulter, B., Rehder, G., Resplandy, L., Robertson, E., Rocher, M., Rödenbeck, C., Schuster, U., Schwinger, J., Séférian, R., Skjelvan, I., Steinhoff, T., Sutton, A., Tans, P. P., Tian, H., Tilbrook, B., Tubiello, F. N., van der Laan-Luijkx, I. T., van der Werf, G. R., Viovy, N., Walker, A. P., Wiltshire, A. J., Wright, R., Zaehle, S., and Zheng, B.: Global Carbon Budget 2018, Earth Syst. Sci. Data, 10, 21412194, https://doi.org/10.5194/essd-10-2141-2018, 2018.

Li, F., Val Martin, M., Hantson, S., Andreae, M. O., Arneth, A., Lasslop, G., Yue, C., Bachelet, D., Forrest, M., Kaiser, J. W., Kluzek, E., Liu, X., Melton, J. R., Ward, D. S., Darmenov, A., Hickler, T., Ichoku, C., Magi, B. I., Sitch, S., van der Werf, G. R., and Wiedinmyer, C.: Historical (1700-2012) Global Multimodel Estimates of the Fire Emissions from the Fire Modeling Intercomparison Project (FireMIP), Atmos. Chem. Phys. Discuss., https://doi.org/10.5194/acp-2019-37, in review, 2019.

Li, H. Y., Lamb, K. D., Schwarz, J. P., Selimovic, V., Yokelson, R. J., McMeeking, G. R., and May, A. A.: Inter-comparison of black carbon measurement methods for simulated open biomass burning emissions, Atmos. Environ., 206, 156-169, https://doi.org/10.1016/j.atmosenv.2019.03.010, 2019.

Lim, C. Y., Hagan, D. H., Coggon, M. M., Koss, A. R., Sekimoto, K., de Gouw, J., Warneke, C., Cappa, C. D., and Kroll, J. H.: Secondary organic aerosol formation from biomass burning emissions, Atmos. Chem. Phys. Discuss., https://doi.org/10.5194/acp-2019-326, in review, 2019.

Liu, S., Aiken, A. C., Arata, C., Dubey, M. K., Stockwell, C. E., Yokelson, R. J., Stone, E. A., Jayarathne, T., Robinson, A. L., DeMott, P. J., and Kreidenweis, S. M., Aerosol single scattering albedo dependence on biomass combustion efficiency: Laboratory and field studies, Geophys. Res. Lett., 41, 742-748, https://doi.org/10.1002/2013GL058392, 2014.

Liu, X., Huey, L. G., Yokelson, R. J., Selimovic, V., Simpson, I. J., Müller, M., Jimenez, J. L., Campuzano-Jost, P., Beyersdorf, A. J., Blake, D. R., Butterfield, Z., Choi, Y., Crounse, J. D., Day, D. A., Diskin, G. S., Dubey, M. K., Fortner, E., Hanisco, T. F., Hu, W., King, L. E., Kleinman, L., Meinardi, S., Mikoviny, T., Onasch, T. B., Palm, B. B., Peischl, J., Pollack, I. B., Ryerson, T. B., Sachse, G. W., Sedlacek, A. J., Shilling, J. E., Springston, S., St. Clair, J. M., Tanner, D. J., Teng, A. P., Wennberg, P. O., Wisthaler, A., and Wolfe, G. M.: Airborne measurements of western U.S. wildfire emissions: Comparison with prescribed burning and air quality implications, J. Geophys. Res., 122, 6108-6129, https://doi.org/10.1002/2016JD026315, 2017.

Lobert, J. M. and Warnatz, J.: Emissions from the combustion process in vegetation, in: Fire in the Environment: The Ecological, Atmospheric, and Climatic Importance of Vegetation Fires, 
edited by: Crutzen, P. J. and Goldammer, J. G., 15-37, J. Wiley \& Sons, Chichester, UK, 1993.

Lutsch, E., Dammers, E., Conway, S., and Strong, K.: Longrange transport of $\mathrm{NH}_{3}, \mathrm{CO}, \mathrm{HCN}$, and $\mathrm{C}_{2} \mathrm{H}_{6}$ from the 2014 Canadian Wildfires, Geophys. Res. Lett., 43, 8286-8297, https://doi.org/10.1002/2016gl070114, 2016.

Mahowald, N., Jickells, T. D., Baker, A. R., Artaxo, P., BenitezNelson, C. R., Bergametti, G., Bond, T. C., Chen, Y., Cohen, D. D., Herut, B., Kubilay, N., Losno, R., Luo, C., Maenhaut, W., McGee, K. A., Okin, G. S., Siefert, R. L., and Tsukuda, S.: Global distribution of atmospheric phosphorus sources, concentrations and deposition rates, and anthropogenic impacts, Global Biogeochem. Cy., 22, GB4026, https://doi.org/10.1029/2008gb003240, 2008.

Malavelle, F. F., Haywood, J. M., Mercado, L. M., Folberth, G. A., Bellouin, N., Sitch, S., and Artaxo, P.: Studying the impact of biomass burning aerosol radiative and climate effects on the Amazon rainforest productivity with an Earth system model, Atmos. Chem. Phys., 19, 1301-1326, https://doi.org/10.5194/acp19-1301-2019, 2019.

May, A. A., Levin, E. J. T., Hennigan, C. J., Riipinen, I., Lee, T., Collett, J. L., Jimenez, J. L., Kreidenweis, S. M., and Robinson, A. L.: Gas-particle partitioning of primary organic aerosol emissions: 3. Biomass burning, J. Geophys. Res., 118, 11327-11338, https://doi.org/10.1002/jgrd.50828, 2013.

McKendry, I. G., Christen, A., Lee, S.-C., Ferrara, M., Strawbridge, K. B., O'Neill, N., and Black, A.: Impacts of an intense wildfire smoke episode on surface radiation, energy and carbon fluxes in southwestern British Columbia, Canada, Atmos. Chem. Phys., 19, 835-846, https://doi.org/10.5194/acp-19-835-2019, 2019.

Mebust, A. K., Russell, A. R., Hudman, R. C., Valin, L. C., and Cohen, R. C.: Characterization of wildfire $\mathrm{NO}_{x}$ emissions using MODIS fire radiative power and OMI tropospheric $\mathrm{NO}_{2}$ columns, Atmos. Chem. Phys., 11, 5839-5851, https://doi.org/10.5194/acp-11-5839-2011, 2011.

Mieville, A., Granier, C., Liousse, C., Guillaume, B., Mouillot, F., Lamarque, J. F., Gregoire, J. M., and Petron, G.: Emissions of gases and particles from biomass burning during the 20th century using satellite data and an historical reconstruction, Atmos. Environ., 44, 1469-1477, https://doi.org/10.1016/j.atmosenv.2010.01.011, 2010.

Mouillot, F., Narasimha, A., Balkanski, Y., Lamarque, J. F., and Field, C. B.: Global carbon emissions from biomass burning in the 20th century, Geophys. Res. Lett., 33, L01801, https://doi.org/10.1029/2005g1024707, 2006.

Naeher, L. P., Brauer, M., Lipsett, M., Zelikoff, J. T., Simpson, C. D., Koenig, J. Q., and Smith, K. R.: Woodsmoke health effects: A review, Inhal. Toxicol., 19, 67-106, https://doi.org/10.1080/08958370600985875, 2007.

Olivier, J. G. J., Aardenne, J. A. V., Dentener, F. J., Pagliari, V., Ganzeveld, L. N., and Peters, J. A. H. W.: Recent trends in global greenhouse gas emissions: Regional trends 1970-2000 and spatial distribution of key sources in 2000, Environ. Sci., 2, 81-99, 2005.

Pacifico, F., Folberth, G. A., Sitch, S., Haywood, J. M., Rizzo, L. V., Malavelle, F. F., and Artaxo, P.: Biomass burning related ozone damage on vegetation over the Amazon forest: a model sensitivity study, Atmos. Chem. Phys., 15, 2791-2804, https://doi.org/10.5194/acp-15-2791-2015, 2015.
Park, K., Emmons, L. K., Wang, Z. H., and Mak, J. E.: Joint application of concentration and $\delta^{18} \mathrm{O}$ to investigate the global atmospheric CO budget, Atmosphere, 6, 547-578, https://doi.org/10.3390/atmos6050547, 2015.

Pechony, O., Shindell, D. T., and Faluvegi, G.: Direct top-down estimates of biomass burning CO emissions using TES and MOPITT versus bottom-up GFED inventory, J. Geophys. Res., 118, 8054-8066, https://doi.org/10.1002/jgrd.50624, 2013.

Rap, A., Spracklen, D. V., Mercado, L., Reddington, C. L., Haywood, J. M., Ellis, R. J., Phillips, O. L., Artaxo, P., Bonal, D., Coupe, N. R., and Butt, N.: Fires increase Amazon forest productivity through increases in diffuse radiation, Geophys. Res. Lett., 42, 4654-4662, https://doi.org/10.1002/2015GL063719, 2015.

Reid, J. S., Koppmann, R., Eck, T. F., and Eleuterio, D. P.: A review of biomass burning emissions part II: intensive physical properties of biomass burning particles, Atmos. Chem. Phys., 5, 799825, https://doi.org/10.5194/acp-5-799-2005, 2005.

Reid, J. S., Hyer, E. J., Prins, E. M., Westphal, D. L., Zhang, J. L., Wang, J., Christopher, S. A., Curtis, C. A., Schmidt, C. C., Eleuterio, D. P., Richardson, K. A., and Hoffman, J. P.: Global Monitoring and Forecasting of Biomass-Burning Smoke: Description of and Lessons From the Fire Locating and Modeling of Burning Emissions (FLAMBE) Program, IEEE J. Sel. Top. Appl., 2, 144-162, https://doi.org/10.1109/jstars.2009.2027443, 2009.

Reisen, F., Meyer, C. P., Weston, C. J., and Volkova, L.: Groundbased field measurements of $\mathrm{PM}_{2.5}$ emission factors from flaming and smoldering combustion in eucalypt forests, J. Geophys. Res., 123, 8301-8314, https://doi.org/10.1029/2018JD028488, 2018.

Rinsland, C. P., Dufour, G., Boone, C. D., Bernath, P. F., Chiou, L., Coheur, P. F., Turquety, S., and Clerbaux, C.: Satellite boreal measurements over Alaska and Canada during June-July 2004: Simultaneous measurements of upper tropospheric $\mathrm{CO}$, $\mathrm{C}_{2} \mathrm{H}_{6}, \mathrm{HCN}, \mathrm{CH}_{3} \mathrm{Cl}, \mathrm{CH}_{4}, \mathrm{C}_{2} \mathrm{H}_{2}, \mathrm{CH}_{3} \mathrm{OH}, \mathrm{HCOOH}, \mathrm{OCS}$, and $\mathrm{SF}_{6}$ mixing ratios, Global Biogeochem. Cy., 21, GB3008, https://doi.org/10.1029/2006gb002795, 2007.

Robertson, K. M., Hsieh, Y. P., and Bugna, G. C.: Fire environment effects on particulate matter emission factors in southeastern U.S. pine-grasslands, Atmos. Environ., 99, 104-111, https://doi.org/10.1016/j.atmosenv.2014.09.058, 2014.

Robinson, A. L., Donahue, N. M., Shrivastava, M. K., Weitkamp, E. A., Sage, A. M., Grieshop, A. P., Lane, T. E., Pierce, J. R., and Pandis, S. N.: Rethinking organic aerosols: Semivolatile emissions and photochemical aging, Science, 315, 1259-1262, 2007.

Rosenfeld, D., Lohmann, U., Raga, G. B., O'Dowd, C. D., Kulmala, M., Fuzzi, S., Reissell, A., and Andreae, M. O.: Flood or drought: How do aerosols affect precipitation?, Science, 321, 1309-1313, 2008.

Rosenfeld, D., Andreae, M. O., Asmi, A., Chin, M., de Leeuw, G., Donovan, D. P., Kahn, R., Kinne, S., Kivekas, N., Kulmala, M., Lau, W., Schmidt, K. S., Suni, T., Wagner, T., Wild, M., and Quaas, J.: Global observations of aerosol-cloudprecipitation-climate interactions, Rev. Geophys., 52, 750-808, https://doi.org/10.1002/2013rg000441, 2014.

Sakamoto, K. M., Laing, J. R., Stevens, R. G., Jaffe, D. A., and Pierce, J. R.: The evolution of biomass-burning aerosol size distributions due to coagulation: dependence on fire and meteorological details and parameterization, Atmos. Chem. Phys., 16, 7709-7724, https://doi.org/10.5194/acp-16-7709-2016, 2016. 
Schreier, S. F., Richter, A., Schepaschenko, D., Shvidenko, A., Hilboll, A., and Burrows, J. P.: Differences in satellitederived $\mathrm{NO}_{x}$ emission factors between Eurasian and North American boreal forest fires, Atmos. Environ., 121, 55-65, https://doi.org/10.1016/j.atmosenv.2014.08.071, 2015.

Sekimoto, K., Koss, A. R., Gilman, J. B., Selimovic, V., Coggon, M. M., Zarzana, K. J., Yuan, B., Lerner, B. M., Brown, S. S., Warneke, C., Yokelson, R. J., Roberts, J. M., and de Gouw, J.: High- and low-temperature pyrolysis profiles describe volatile organic compound emissions from western US wildfire fuels, Atmos. Chem. Phys., 18, 9263-9281, https://doi.org/10.5194/acp18-9263-2018, 2018.

Selimovic, V., Yokelson, R. J., Warneke, C., Roberts, J. M., de Gouw, J., Reardon, J., and Griffith, D. W. T.: Aerosol optical properties and trace gas emissions by PAX and OP-FTIR for laboratory-simulated western US wildfires during FIREX, Atmos. Chem. Phys., 18, 2929-2948, https://doi.org/10.5194/acp18-2929-2018, 2018.

Selimovic, V., Yokelson, R. J., McMeeking, G. R., and Coefield, S.: In situ measurements of trace gases, PM, and aerosol optical properties during the 2017 NW US wildfire smoke event, Atmos. Chem. Phys., 19, 3905-3926, https://doi.org/10.5194/acp19-3905-2019, 2019.

Shiraiwa, M., Ueda, K., Pozzer, A., Lammel, G., Kampf, C. J., Fushimi, A., Enami, S., Arangio, A. M., Fröhlich-Nowoisky, J., Fujitani, Y., Furuyama, A., Lakey, P. S. J., Lelieveld, J., Lucas, K., Morino, Y., Pöschl, U., Takahama, S., Takami, A., Tong, H., Weber, B., Yoshino, A., and Sato, K.: Aerosol health effects from molecular to global scales, Environ. Sci. Technol., 51, 1354513567, https://doi.org/10.1021/acs.est.7b04417, 2017.

Sirithian, D., Thepanondh, S., Sattler, M. L., and Laowagul, W.: Emissions of volatile organic compounds from maize residue open burning in the northern region of Thailand, Atmos. Environ., 176, 179-187, https://doi.org/10.1016/j.atmosenv.2017.12.032, 2018.

Smith, J. N., Barsanti, K. C., Friedli, H. R., Ehn, M., Kulmala, M., Collins, D. R., Scheckman, J. H., Williams, B. J., and McMurry, P. H.: Observations of aminium salts in atmospheric nanoparticles and possible climatic implications, P. Natl. Acad. Sci. USA, 107, 6634-6639, https://doi.org/10.1073/pnas.0912127107, 2010.

Soares Neto, T. G., Carvalho Jr., J. A., Veras, C. A. G., Alvarado, E. C., Gielow, R., Lincoln, E. N., Christian, T. J., Yokelson, R. J., and Santos, J. C.: Biomass consumption and $\mathrm{CO}_{2}, \mathrm{CO}$ and main hydrocarbon gas emissions in an Amazonian forest clearing fire, Atmos. Environ., 43, 438-446, https://doi.org/10.1016/j.atmosenv.2008.07.063, 2009.

Stockwell, C. E., Veres, P. R., Williams, J., and Yokelson, R. J.: Characterization of biomass burning emissions from cooking fires, peat, crop residue, and other fuels with high-resolution proton-transfer-reaction time-of-flight mass spectrometry, Atmos. Chem. Phys., 15, 845-865, https://doi.org/10.5194/acp-15845-2015, 2015.

Stockwell, C. E., Christian, T. J., Goetz, J. D., Jayarathne, T., Bhave, P. V., Praveen, P. S., Adhikari, S., Maharjan, R., DeCarlo, P. F., Stone, E. A., Saikawa, E., Blake, D. R., Simpson, I. J., Yokelson, R. J., and Panday, A. K.: Nepal Ambient Monitoring and Source Testing Experiment (NAMaSTE): emissions of trace gases and light-absorbing carbon from wood and dung cooking fires, garbage and crop residue burning, brick kilns, and other sources, Atmos. Chem. Phys., 16, 11043-11081, https://doi.org/10.5194/acp-16-11043-2016, 2016 a.

Stockwell, C. E., Jayarathne, T., Cochrane, M. A., Ryan, K. C., Putra, E. I., Saharjo, B. H., Nurhayati, A. D., Albar, I., Blake, D. R., Simpson, I. J., Stone, E. A., and Yokelson, R. J.: Field measurements of trace gases and aerosols emitted by peat fires in Central Kalimantan, Indonesia, during the 2015 El Niño, Atmos. Chem. Phys., 16, 11711-11732, https://doi.org/10.5194/acp-16-117112016, 2016 b.

Takahama, S., Schwartz, R. E., Russell, L. M., Macdonald, A. M., Sharma, S., and Leaitch, W. R.: Organic functional groups in aerosol particles from burning and non-burning forest emissions at a high-elevation mountain site, Atmos. Chem. Phys., 11, 6367-6386, https://doi.org/10.5194/acp-11-6367-2011, 2011.

Tereszchuk, K. A., González Abad, G., Clerbaux, C., Hurtmans, D., Coheur, P.-F., and Bernath, P. F.: ACE-FTS measurements of trace species in the characterization of biomass burning plumes, Atmos. Chem. Phys., 11, 12169-12179, https://doi.org/10.5194/acp-11-12169-2011, 2011.

Tereszchuk, K. A., González Abad, G., Clerbaux, C., Hadji-Lazaro, J., Hurtmans, D., Coheur, P.-F., and Bernath, P. F.: ACE-FTS observations of pyrogenic trace species in boreal biomass burning plumes during BORTAS, Atmos. Chem. Phys., 13, 4529-4541, https://doi.org/10.5194/acp-13-4529-2013, 2013.

Thompson, R. J., Li, J., Weyant, C. L., Edwards, R., Lan, Q., Rothman, N., Hu, W., Dang, J., Dang, A., Smith, K. R., and Bond, T. C., Field emission measurements of solid fuel stoves in Yunnan, China demonstrate dominant causes of uncertainty in household emission inventories, Environ. Sci. Technol., 53, 3323-3330, https://doi.org/10.1021/acs.est.8b07040, 2019.

Thornhill, G. D., Ryder, C. L., Highwood, E. J., Shaffrey, L. C., and Johnson, B. T.: The effect of South American biomass burning aerosol emissions on the regional climate, Atmos. Chem. Phys., 18, 5321-5342, https://doi.org/10.5194/acp-185321-2018, 2018.

Tian, H., Lu, C., Ciais, P., Michalak, A. M., Canadell, J. G., Saikawa, E., Huntzinger, D. N., Gurney, K. R., Sitch, S., Zhang, B., Yang, J., Bousquet, P., Bruhwiler, L., Chen, G., Dlugokencky, E., Friedlingstein, P., Melillo, J., Pan, S., Poulter, B., Prinn, R., Saunois, M., Schwalm, C. R., and Wofsy, S. C.: The terrestrial biosphere as a net source of greenhouse gases to the atmosphere, Nature, 531, 225-228, https://doi.org/10.1038/nature16946, 2016.

Tian, J., Wang, Q., Ni, H., Wang, M., Zhou, Y., Han, Y., Shen, Z., Pongpiachan, S., Zhang, N., Zhao, Z., Zhang, Q., Zhang, Y., Long, X., and Cao, J.: Emission characteristics of primary brown carbon absorption from biomass and coal burning: Development of an optical emission inventory for China, J. Geophys. Res., 124, 1879-1893, https://doi.org/10.1029/2018JD029352, 2019.

Tkacik, D. S., Robinson, E. S., Ahern, A., Saleh, R., Stockwell, C., Veres, P., Simpson, I. J., Meinardi, S., Blake, D. R., Yokelson, R. J., Presto, A. A., Sullivan, R. C., Donahue, N. M., and Robinson, A. L.: A dual-chamber method for quantifying the effects of atmospheric perturbations on secondary organic aerosol formation from biomass burning emissions, J. Geophys. Res., 122, 6043-6058, https://doi.org/10.1002/2016JD025784, 2017.

Tosca, M. G., Randerson, J. T., and Zender, C. S.: Global impact of smoke aerosols from landscape fires on climate and 
the Hadley circulation, Atmos. Chem. Phys., 13, 5227-5241, https://doi.org/10.5194/acp-13-5227-2013, 2013.

Turpin, B. J. and Lim, H.-J.: Species contributions to $\mathrm{PM}_{2.5}$ mass concentrations: Revisiting common assumptions for estimating organic mass, Aerosol Sci. Tech., 35, 602-610, 2001.

Urbanski, S.: Wildland fire emissions, carbon, and climate: Emission factors, Forest Ecol. Manag., 317, 51-60, https://doi.org/10.1016/j.foreco.2013.05.045, 2014.

Urbanski, S. P.: Combustion efficiency and emission factors for wildfire-season fires in mixed conifer forests of the northern Rocky Mountains, US, Atmos. Chem. Phys., 13, 7241-7262, https://doi.org/10.5194/acp-13-7241-2013, 2013.

Urbanski, S. P., Hao, W. M., and Baker, S.: Chemical composition of wildland fire emissions, in: Wildland Fires and Air Pollution, edited by: Bytnerowicz, A., Arbaugh, M. J., Riebau, A. R., and Andersen, C., 79-107, https://doi.org/10.1016/s14748177(08)00004-1, 2009.

van der Werf, G. R., Randerson, J. T., Giglio, L., van Leeuwen, T. T., Chen, Y., Rogers, B. M., Mu, M., van Marle, M. J. E., Morton, D. C., Collatz, G. J., Yokelson, R. J., and Kasibhatla, P. S.: Global fire emissions estimates during 1997-2016, Earth Syst. Sci. Data, 9, 697-720, https://doi.org/10.5194/essd-9-697-2017, 2017.

Viatte, C., Strong, K., Hannigan, J., Nussbaumer, E., Emmons, L. K., Conway, S., Paton-Walsh, C., Hartley, J., Benmergui, J., and Lin, J.: Identifying fire plumes in the Arctic with tropospheric FTIR measurements and transport models, Atmos. Chem. Phys., 15, 2227-2246, https://doi.org/10.5194/acp-152227-2015, 2015.

Ward, D. E. and Hardy, C. C.: Smoke emissions from wildland fires, Environ. Int., 17, 117-134, 1991.

Ward, D. E. and Radke, L. F.: Emissions measurements from vegetation fires: A comparative evaluation of methods and results, in: Fire in the Environment: The Ecological, Atmospheric, and Climatic Importance of Vegetation Fires, edited by:. Crutzen, P. J and Goldammer, J. G., 53-76, J. Wiley \& Sons, Chichester, UK, 1993.

Ward, D. E., Susott, R. A., Kauffman, J. B., Babbitt, R. E., Cummings, D. L., Dias, B., Holben, B. N., Kaufman, Y. J., Rasmussen, R. A., and Setzer, A. W.: Smoke and fire characteristics for cerrado and deforestation burns in Brazil: BASE-B experiment, J. Geophys. Res., 97, 14601-14619, 1992.

Ward, D. S., Kloster, S., Mahowald, N. M., Rogers, B. M., Randerson, J. T., and Hess, P. G.: The changing radiative forcing of fires: global model estimates for past, present and future, Atmos. Chem. Phys., 12, 10857-10886, https://doi.org/10.5194/acp-1210857-2012, 2012.

Wiedinmyer, C., Akagi, S. K., Yokelson, R. J., Emmons, L. K., AlSaadi, J. A., Orlando, J. J., and Soja, A. J.: The Fire INventory from NCAR (FINN): a high resolution global model to estimate the emissions from open burning, Geosci. Model Dev., 4, 625641, https://doi.org/10.5194/gmd-4-625-2011, 2011.
Wiedinmyer, C., Yokelson, R. J., and Gullett, B. K.: Global emissions of trace gases, particulate matter, and hazardous air pollutants from open burning of domestic waste, Environ. Sci. Technol., 48, 9523-9530, https://doi.org/10.1021/es502250z, 2014.

Yevich, R. and Logan, J. A.: An assessment of biofuel use and burning of agricultural waste in the developing world, Global Biogeochem. Cy., 17, 1095, https://doi.org/10.1029/2002GB001952, 2003.

Yokelson, R. J., Griffith, D. W. T., and Ward, D. E.: Openpath fourier-transform infrared studies of large-scale laboratory biomass fires, J. Geophys. Res., 101, 21067-21080, 1996.

Yokelson, R. J., Susott, R., Ward, D. E., Reardon, J., and Griffith, D. W. T.: Emissions from smoldering combustion of biomass measured by open-path Fourier transform infrared spectroscopy, J. Geophys. Res., 102, 18865-18877, 1997.

Yokelson, R. J., Bertschi, I. T., Christian, T. J., Hobbs, P. V., Ward, D. E., and Hao, W. M.: Trace gas measurements in nascent, aged, and cloud-processed smoke from African savanna fires by airborne Fourier transform infrared spectroscopy (AFTIR), J. Geophys. Res., 108, 8478, https://doi.org/10.1029/2002JD002322, 2003.

Yokelson, R. J., Christian, T. J., Karl, T. G., and Guenther, A.: The tropical forest and fire emissions experiment: laboratory fire measurements and synthesis of campaign data, Atmos. Chem. Phys., 8, 3509-3527, https://doi.org/10.5194/acp-8-3509-2008, 2008.

Yokelson, R. J., Crounse, J. D., DeCarlo, P. F., Karl, T., Urbanski, S., Atlas, E., Campos, T., Shinozuka, Y., Kapustin, V., Clarke, A. D., Weinheimer, A., Knapp, D. J., Montzka, D. D., Holloway, J., Weibring, P., Flocke, F., Zheng, W., Toohey, D., Wennberg, P. O., Wiedinmyer, C., Mauldin, L., Fried, A., Richter, D., Walega, J., Jimenez, J. L., Adachi, K., Buseck, P. R., Hall, S. R., and Shetter, R.: Emissions from biomass burning in the Yucatan, Atmos. Chem. Phys., 9, 5785-5812, https://doi.org/10.5194/acp-9-57852009, 2009.

Yokelson, R. J., Andreae, M. O., and Akagi, S. K.: Pitfalls with the use of enhancement ratios or normalized excess mixing ratios measured in plumes to characterize pollution sources and aging, Atmos. Meas. Tech., 6, 2155-2158, https://doi.org/10.5194/amt6-2155-2013, 2013a.

Yokelson, R. J., Burling, I. R., Gilman, J. B., Warneke, C., Stockwell, C. E., de Gouw, J., Akagi, S. K., Urbanski, S. P., Veres, P., Roberts, J. M., Kuster, W. C., Reardon, J., Griffith, D. W. T., Johnson, T. J., Hosseini, S., Miller, J. W., Cocker III, D. R., Jung, H., and Weise, D. R.: Coupling field and laboratory measurements to estimate the emission factors of identified and unidentified trace gases for prescribed fires, Atmos. Chem. Phys., 13, 89-116, https://doi.org/10.5194/acp-13-89-2013, 2013b.

Yue, $X$. and Unger, N.: Fire air pollution reduces global terrestrial productivity, Nat. Commun., 9, 5413, https://doi.org/10.1038/s41467-018-07921-4, 2018. 